Article

\title{
The Effect of Fire on Building Materials: The Case-Study of the Varnakova Monastery Cells in Central Greece
}

\author{
Ekaterini T. Delegou ${ }^{1, *}$, Maria Apostolopoulou ${ }^{1}$, Ioanna Ntoutsi ${ }^{1}$, Marina Thoma ${ }^{1}$, \\ Vasileios Keramidas ${ }^{1}$, Christos Papatrechas ${ }^{2}$, George Economou ${ }^{2}$ and Antonia Moropoulou ${ }^{1, *}$ \\ 1 Laboratory of Materials Science \& Engineering, School of Chemical Engineering, National Technical \\ University of Athens (NTUA), 9 Iroon Polytechniou Str., Zografou Campus, 15780 Athens, Greece; \\ mairi_apostol@hotmail.com (M.A.); ioanna_ntoutsi@yahoo.gr (I.N.); marina_tho@hotmail.com (M.T.); \\ bkeramidas@hotmail.gr (V.K.) \\ 2 Institute of Geology and Mineral Exploration (I.G.M.E.), Mineralogy and Petrology Department, \\ 1 Spyrou Loui, Acharnes, 13677 Eastern Attica, Greece; papatrechas@windowslive.com (C.P.); \\ georgeoik7@gmail.com (G.E.) \\ * Correspondence: edelegou@central.ntua.gr (E.T.D.); amoropul@central.ntua.gr (A.M.); \\ Tel.: +30-2107-723-075 (E.T.D.); +30-2107-723-276 (A.M.)
}

Received: 21 February 2019; Accepted: 17 April 2019; Published: 20 April 2019 updates

\begin{abstract}
The evaluation of the fire impact on building materials is of great scientific and socio-economic importance since fire can result in materials' chemical and mechanical alterations, which leads to structural stability problems of historical and/or modern construction. This highly increases the cost of rehabilitation interventions. The case study of the Byzantine Monastery of Panagia (Virgin Mary) Varnakova is an example of the fire effect on both historical and newer stone masonries. The Varnakova Monastery is a typical 19th century monastic complex and, during its long history, it has undergone multiple reconstructions after major catastrophic events that have taken place due to its strategic geographical position and its financial and spiritual significance for the region. The last big-scale renovation of the Monastery was conducted between the years 1992 to 2014. However, in January 2017, a devastating fire destroyed the largest part of the monastic cells' quarter. In this work, a diagnostic study of the different construction phases' materials comprising the masonries of the monastery cells in their present state is presented. The examination of a series of samples through analytical techniques, such as optical microscopy, X-ray diffraction, thermal analysis, and total immersion tests, along with the use of non-destructive techniques in situ, such as Infra Red Thermography, Digital Microscopy, and Schmidt Hammer Rebound tests, shed light on the preservation state and on the decay of the diverse building materials. In addition, the impact of the fire on their properties was investigated. The results reveal the diversity of the materials used in the historical masonries throughout the centuries, while the combination of analytical and non-destructive techniques demonstrates the damages induced by the fire.
\end{abstract}

Keywords: stone; mortar; masonry; fire; NDT; IRT; SHR; microscopy; petrography; XRD; TG/DTA

\section{Introduction}

In recent years, more research has focused on the effect of high temperatures on building materials [1-16]. The development of high temperatures affects the various characteristics of a material. Petrographic, mineralogical, chemical, physical, and mechanical properties may alter, depending on the temperatures developed, the characteristics of the material, the timeframe of the high temperature event, and the manner of cooling. The assessment of the effect of high temperatures on the building 
materials of a structure, especially after a catastrophic event, such as a fire, is crucial in order to evaluate the safety level of its damaged state and plan appropriate repair measures [10]. This assessment is even more important in the case of monumental structures, where the historic building materials are "precious" and should, if possible, be replaced to the minimum extent.

The effect of high temperature on a building material is a complex mechanism and various material properties must be examined in order to obtain a holistic view of a fire effect. Visual inspection provides useful information regarding the effect of a fire event, since many damages and decay patterns are macroscopically manifested, including cracking, surface crazing, deflection, delamination, color changes, and smoke damage $[12,13,15,16]$.

Petrographic analysis assists not only in the characterization of a stone type, which reveals composition, texture, binder type, and micro-morphology, but in the evaluation of the effect of high temperature as well, by examining the alterations observed in these characteristics $[2,4-7,10]$. A temperature increase induces inter-granular and intra-granular effects on a material while inter-granular effects are connected to the development of microcracks within the matrix of the material and are usually the result of different characteristics of the material's constituents. Intra-granular effects manifest through the development of microcracks within the grains themselves [1]. Inherent anisotropy of materials is an example of degradation in the case of thermal loads. For example, inherent anisotropy of calcite grains, when heated, is considered to be the main agent for marble and limestones disintegration [11,13]. Mineralogical analysis reveals the alteration of mineralogical compounds. Thus, the absence or decrease of a compound after the fire event is indicative that the fire reached a temperature at which the compound's structure irreversibly collapses and/or is transformed into an amorphous compound that is no longer detectable [2]. Chemical analysis can reveal alterations in the composition of the material, which is also connected to transformations that take place during the fire effect. These alterations include oxidation, dehydration, de-hydroxylation, calcination, and other processes $[6,14]$. These processes may infer matrix alterations of a building material and/or color changes, such as reddening (e.g., when ferrous minerals are included in the material). Thus, for example, the clay and iron oxides-hydroxides content within a stone or aggregates of a mortar may be a determinant for a series of transformations induced by heat [16].

Microstructural analysis is of paramount importance since the alteration of microstructural characteristics affects other properties, such as the behavior of a material under hygro-thermic loads and compressive strength $[1-7,9]$. Porosity usually increases when a material is subjected to high temperatures [1,3], while density decreases due to material loss and compound decomposition, dehydroxilation, and dehydration processes. Mechanical characteristics are crucial to structural stability. Compressive strength usually decreases due to the development of microcracks and/or the increase of porosity $[8,9]$.

The effect of fire and the consequent alterations induced to a material's characteristics is clearly dependent on the material itself. In the case of stones, each lithotype presents a different behavior to fire-attack, depending on pertrographic characteristics, chemical composition, porosity, anisotropy of its components, etc. For example, granites are more prone to crack when thermally shocked, in comparison with other softer stones [5]. In quartz-rich sandstones, due to the open porosity they exhibit, as well as due to their calcitic matrix (which undergoes a parallel calcining process), micro-strains due to quartz expansion (when it is transformed from $\alpha \rightarrow \beta$ at $\sim 575^{\circ} \mathrm{C}$ ), are absorbed by the matrix [1]. Thus, knowledge of the type of stone and parallel evaluation of alterations studied in related research and practice can assist in predicting the alterations induced in a certain lithotype in the event of a fire [12].

In terms of physico-mechanical and structural stability of the monument, it is crucial to assess the impact of fire damage. In an extent to the above discussion, the indirect consequences to the whole masonry need to be taken under consideration, during a diagnostic study. Another important aspect to be explored is the variability of the fire impact parameters on the different lithotypes and parts of the masonry depending on the diverse temperatures, duration of the event, or other synergic factors (e.g., precedent defaults of a masonry block or an isolated stone). Mortars, depending on the mortar type, 
may be more or less resistant to a fire event. For example, concrete presents low thermal diffusivity and high incombustibility. However, the decrease in its load-bearing capability and its "explosive spalling" due to the fire action may compromise these assets, especially when the fire temperature exceeds $300^{\circ} \mathrm{C}[15,16]$. Taking into account all the above, the fire impact needs to be addressed initially in terms of building materials. However, it aims to a holistic perspective by studying the structure as a whole.

Within the above framework, this study is an attempt to investigate the effect of the 2017 fire event on the Varnakova Monastery building materials and the masonries they comprise. Hereby, the preliminary results of a diagnostic study through an in situ non-destructive testing and an in-lab application of analytical techniques on selected samples are presented, which aim to understand the effect of the fire on the different lithotypes and mortars comprising the masonries of this historic structure.

\section{Materials and Methods}

\subsection{The Varnakova Monastery}

The Byzantine Monastery of Panagia (Virgin Mary) Varnakova is located on a mountainous landscape of Southwest Central Greece, at an altitude of $800 \mathrm{~m}$ (Figure 1a). Its general structure follows the typical 19th century of a monastic complex with an almost-rectangular courtyard and a church (catholicon) in the center (Figure 1b, topographic depiction: Figure 1c) [17]. The evolution of the architectural phases of the catholicon until the 13th century is reflected in the $\mathrm{Ch}$. Bouras drawing (Figure 1d) [18].
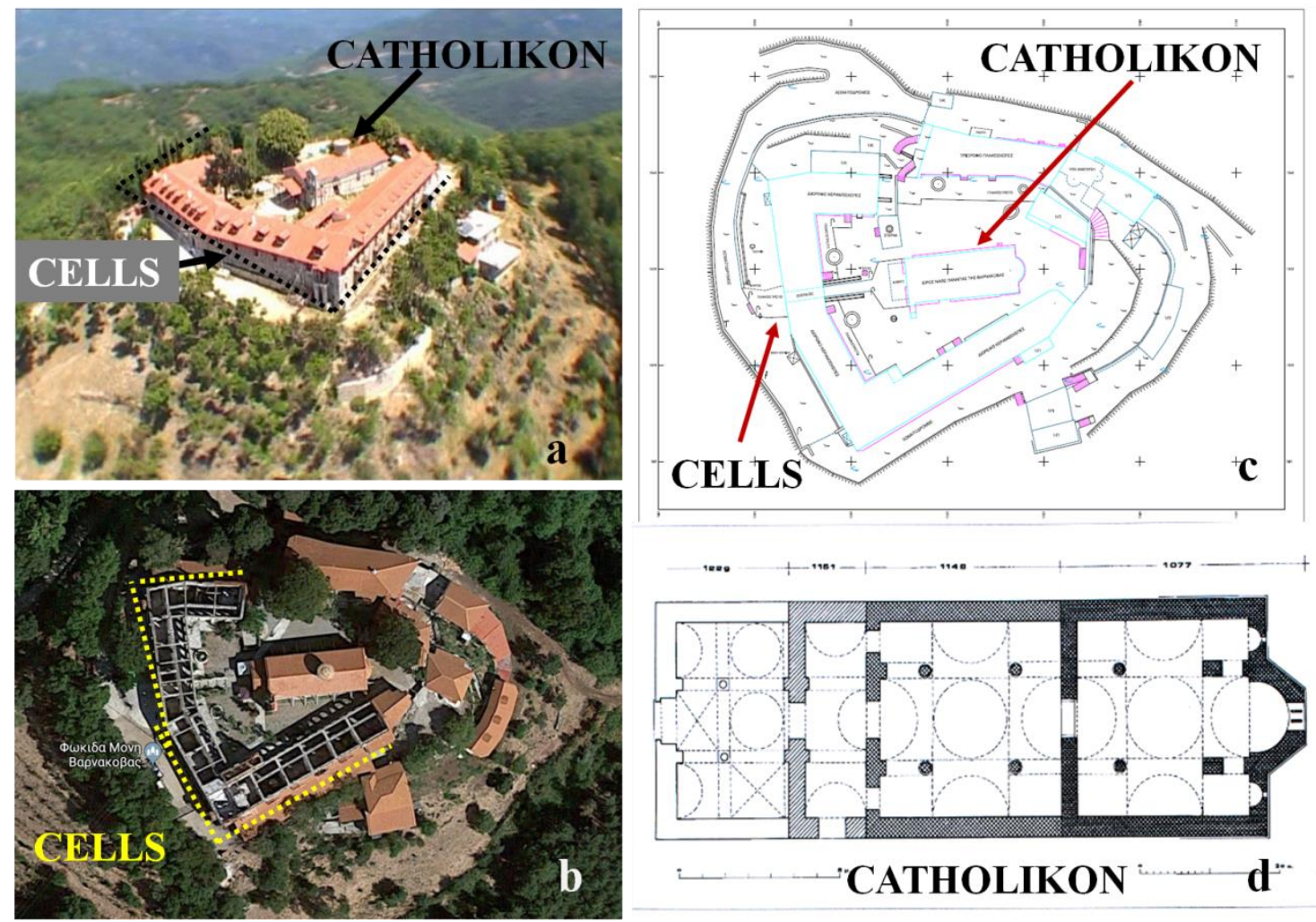

Figure 1. (a) A general photo of the Varnakova Monastery before the 2017 fire. Arrows and dotted lines indicate the cells' section and the catholicon. (b) A general photo of the Varnakova Monastery after the fire - yellow dotted lines indicate the burnt cells' area. (c) A topographical depiction of the complex by Rural and Survey Engineer S. Zacharopoulos [19]. (d) The ground plan of Ch. Bouras depicting the four architectural phases of the catholicon between the 11th and 13th centuries [18]. 
The first church was founded in 1077 AD by Saint Arsenios Varnakovitis. During the 11th and 12th century, it was decorated with wall paintings and on-floor marble mosaics, while the extended renovation of 1148-1151 was fostered by the Byzantine emperors of the Comnenian Dynasty, some of whom were buried beneath the monastery, as referred by A. Orlandos in his 1922 study [20]. The church, as it was at the time of Orlandos's inspection, is referred to as a three-aisled basilica with a narthex and a main altar [21].

The monastery was almost completely destroyed in 1826, as it served as refuge and base during the Greek War of Independence (1821-1830) against the Ottoman Empire. The reconstruction works commenced soon after the liberation, in 1831, according to the plans made by the architect Andreas Gasparis Kalandros, an army lieutenant, and were completed by three Epirot masons by 1838 . This is also the year of the construction of the wooden temple of the catholicon. A. Orlandos uses the term "hammered limestones" to describe the chosen building material used in this construction phase [17,21].

Between the years 1992-2014, the monastery was extensively renovated. On 29 January 2017, a devastating fire started due to a boiler explosion destroyed the largest part of the monastic cells' quarter [22]. Thus today, the monastery cells are in a state of collapse and in need of major restoration and rebuilding (Figure 2).

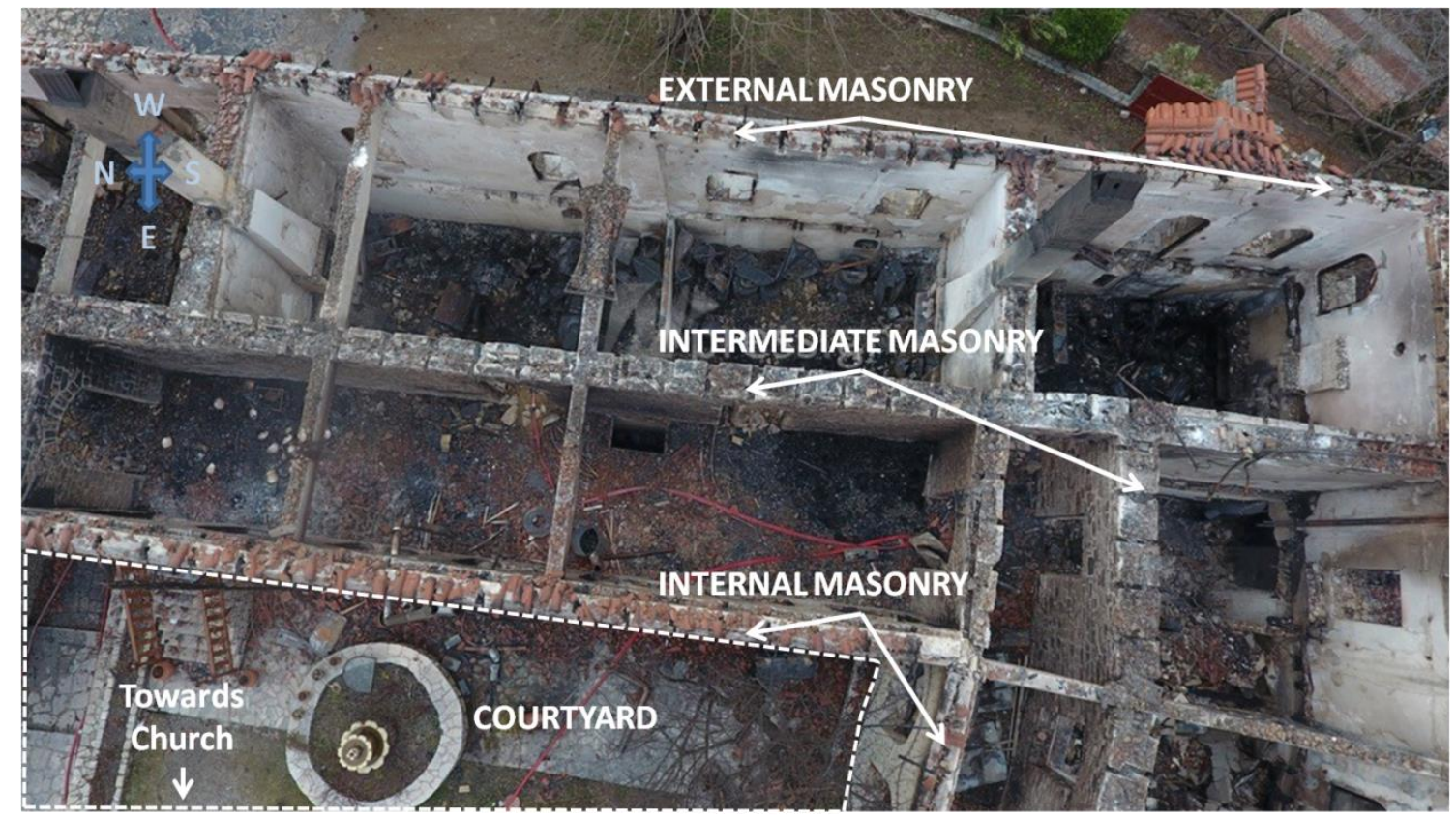

Figure 2. Depiction of the Monastery cells in its present state after the fire, which indicates the external, the intermediate, and the internal masonry. The church, as indicated, is to the east.

\subsection{Visual Inspection}

The external (Figure 2, Figure 3a) and the intermediate masonry (Figure 2, Figure 3d,e) of the cells' quarter belong to the 1831-1838 construction phase, referred to as historic masonries. It should be noted that, during the aforementioned construction phase, the intermediate masonry was, in fact, the masonry surrounding the internal courtyard and directly facing the Church. The historical masonries of this phase were constructed using two main lithotypes: a) a grey-beige limestone, which occasionally appears with black veins and b) sandstones of greenish to brownish shade. In some areas, a black compact stone has also been sporadically used. At certain areas of the intermediate masonry, relatively recent repointing seems to have taken place. 


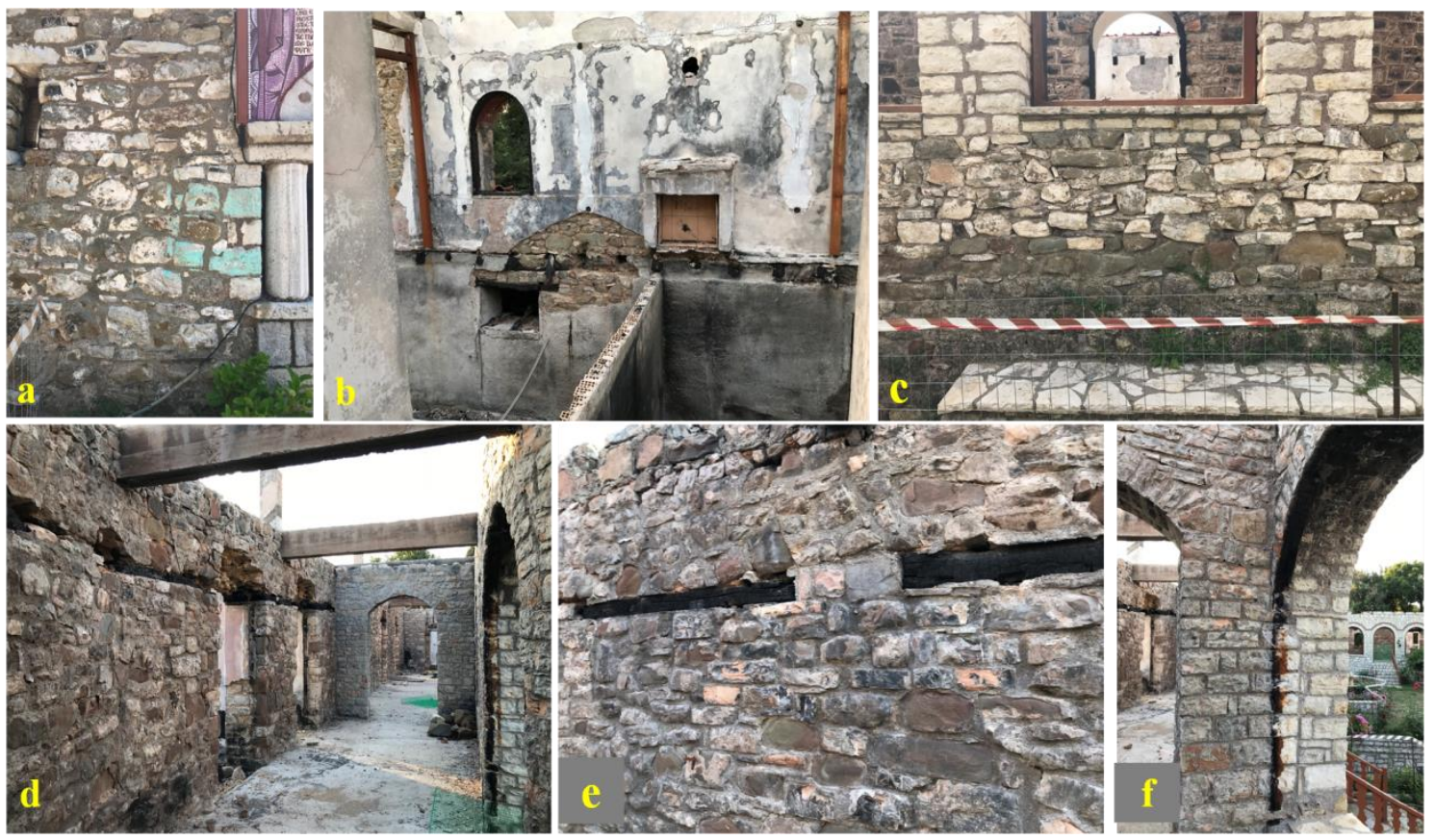

Figure 3. Different areas of the cells quarter: (a) the exterior of the external wall (historic masonry), (b) the plastered interior façade of the external wall presenting severe damages from the fire (historic masonry), (c) the lower part of the internal wall facing the courtyard (new masonry raised on a historic base), (d) the historic intermediate masonry, (e) detail from the fire-affected intermediate masonry, and (f) the new masonry of the cells' quarter: its exterior façade seems intact after the fire, while its interior has suffered fire damage.

The internal masonry (Figure 2, Figure 3c,f), which faces the courtyard and the church today, was added during the major reconstruction that took place after 1992. This aims to improve residential functionality. This new restoration masonry, which is referred to as new masonry, was raised on an already existing base (19th century construction phase). The building stone used for the construction of the interior masonry was a freshly-quarried grey-beige limestone, which greatly resembles the limestone used in the 19th century construction phase masonries.

The visual inspection of the fire-exposed masonries allowed for the following observations:

i. The exterior façade of the external masonry (Figure 3a), which faces to the west, does not present any apparent damage from the fire. The interior plastered facade (Figure 3b) has clearly been affected, which displays blackened areas from the smoke produced during the fire, while partial plaster detachments can be noticed. Unfortunately, the total destruction of the wooden floors restricted access to these areas during this preliminary study.

ii. The historic intermediate masonry seems to have been severely affected by the fire (Figure 3d,e). Its building materials present several damages and stone decay patterns such as color change, spalling, and flaking (Figure 4a). The western façade of this masonry (interior of domestic cells) was covered in plaster including remnants that still remain.

iii. Finally, the new masonry was strongly affected by the fire on its western façade (the one facing the cells corridor). However, its eastern façade (the one facing the courtyard) seems to be unaffected (Figure 3f, Figure 4b). 


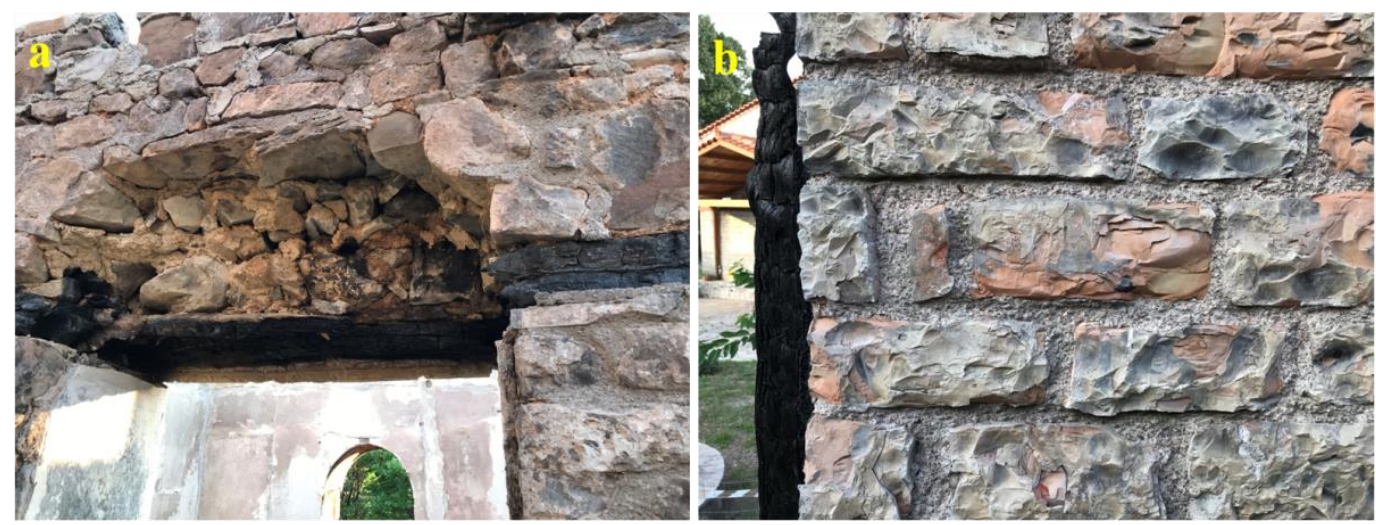

Figure 4. (a) Collapse of building materials from the upper part of the intermediate masonry. (b) Discolorations and scaling of the beige-grey limestone on the interior (western) façade of the new masonry.

\subsection{Investigation Techniques and Methodology}

A variety of techniques were used in the current study, which aim to evaluate the preservation state of the masonries and their building materials comprising them, after the effect of fire. Due to the different exposure of the building materials to the fire event, it was possible to select samples with a varying degree of fire damage, which is affected and not affected. This facilitated the evaluation of the fire effect on the examined building materials.

Analytical techniques were applied in the lab after sampling and were used in order to characterize the building materials and diagnose their decay due to the fire effect. Optical microscopy (OM) was employed for the petrographic characterization of the stone samples, using a ZEISS-AXIOSKOP 40 microscope, while a ProgRes-C14PLUS camera and ProgRes Capture Pro2.1 software were used for taking and editing microphotographs of the samples. Digital Microscopy (DM, i-scope, Moritex) was applied to examine the morphology and texture of the mortars under investigation. X-Ray Diffraction (XRD), using an Advanced D8 Diffractometer by Bruker, was applied for the identification of the crystalline compounds of selected stone and mortar samples, which aim to ascertain the mineralogical transformations due to the fire. Simultaneous Differential Thermal and Thermogravimetric Analysis (DTA/TG, Regulus 2500, Netzsch) was implemented on selected stone and mortar samples for the qualitative and quantitative determination of their compounds. The analyses were carried out at $30-1000{ }^{\circ} \mathrm{C}$ temperature range with a heating rate of $10{ }^{\circ} \mathrm{C} / \mathrm{min}$ in a nitrogen atmosphere. Selected stone and mortar samples also underwent total water immersion tests [23], which aim to estimate the porosity accessible to water by total immersion for each sample, their water absorption capacity and apparent density, and, consequently, the alterations of these characteristics due to the fire effect.

In addition to the analytical techniques, non destructive techniques (NDTs) were applied in situ. In particular, Schmidt hammer rebound tests (SHR) were conducted on several building stones from various areas of the cell masonries in order to evaluate surface hardness of the various lithotypes [24-26] as well as its modification due to the fire effect. A Proceq N-type hammer (impact energy: $2.207 \mathrm{~N} \mathrm{~m}$ ) was used, which followed the operation guidelines [27]. An average of $10 \mathrm{impacts}$ was performed on each of the examined building elements. All tests were performed with the hammer held perpendicular to the examined surface. For the statistical elaboration of the results, both the mean value $(\mathrm{Rm})$ and the median value (RM) were calculated, while, in order to compare the dispersion of the measurements, the coefficient of variation (COV) was also estimated.

Infra-Red Thermography (IRT, B200, FLIR) was used to evaluate the preservation state of the masonry as a whole, by investigating representative areas [28-30]. The passive approach implemented aimed to reveal any temperature gradations of the different building materials consisting of the masonry after the fire effect. 
The methodological approach followed in this study is schematically represented in Figure 5. The evaluation was conducted on two levels: building elements scale and masonry scale. The evaluation on material level is necessary in order to succeed in the evaluation on the masonry level, since the individual materials comprise and, therefore, affect the overall performance of the masonry.

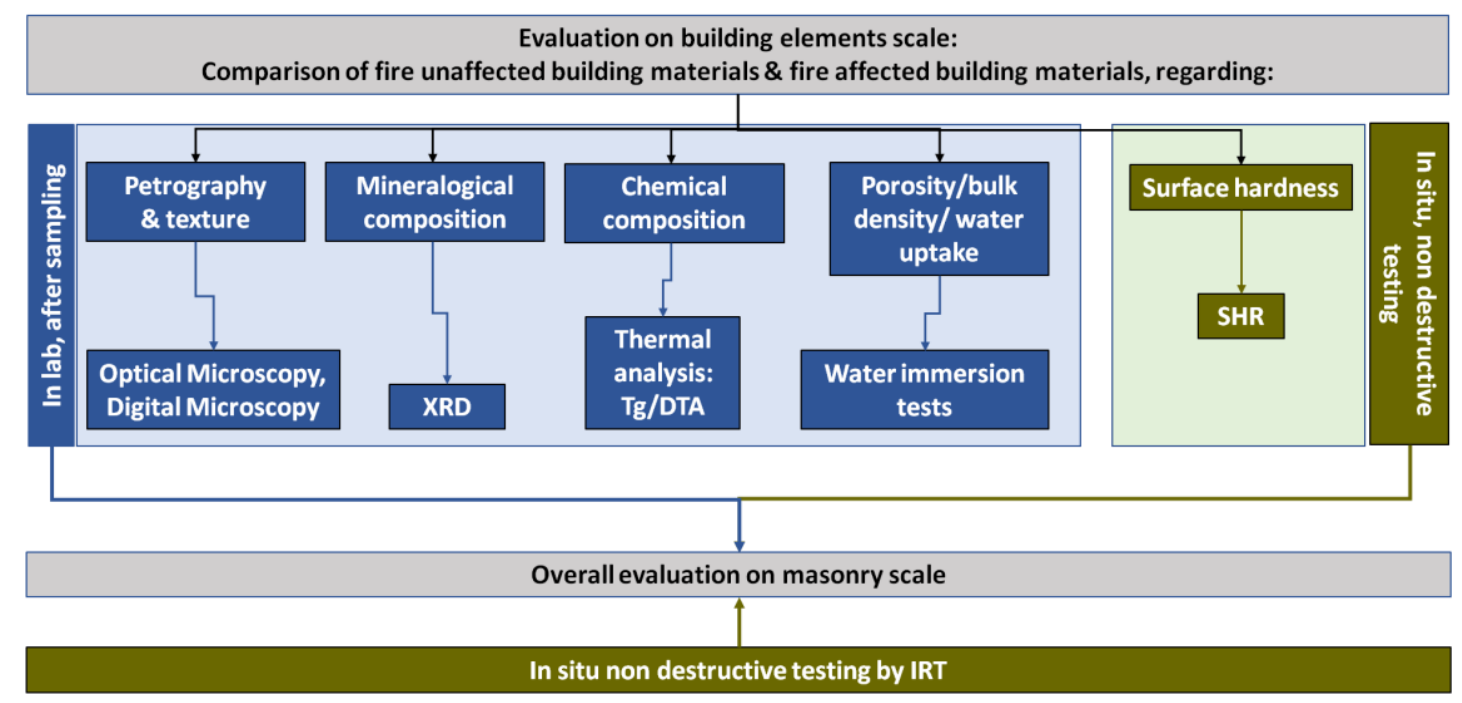

Figure 5. Diagram summarizing the methodological approach followed in this study.

The evaluation on building materials scale was conducted both in lab and in situ. The in lab evaluation aimed to reveal petrography and texture characteristics of the various building materials, their mineralogical and chemical composition, and physical characteristics, such as porosity, bulk density, and water uptake. In the present study, OM, DM, XRD, TG/DTA, and total water immersion tests were conducted in lab for the previously mentioned purposes. The in situ evaluation on building materials scale, aimed to estimate their surface hardness, using SHR. All the above measurements were applied on both fire-affected and seemingly unaffected stone elements in order to achieve a comparison of their properties' modification because of the fire event. In situ non destructive testing by IRT was used as a tool in order to evaluate the preservation state of the masonry (masonry scale) in its current condition (fire-affected). The evaluation on building material scale assists in the interpretation of the IRT results and, consequently, in the assessment of the overall preservation state of the masonry as a whole.

\section{Results and Discussion}

\subsection{Characterization of the Building Materials}

\subsubsection{Investigation of the Building Stones}

The stone samples selected for in-lab examination are described in the following table (Table 1). The stone samples were collected from fire affected and seemingly unaffected areas of the masonry. 
Table 1. Description of the selected stone samples from the cells' quarter.

\begin{tabular}{cc}
\hline Stone Sample Code & Sample Description \\
V1 & $\begin{array}{r}\text { Sandstone of green hue. Collected from intermediate historic masonry, which is seemingly unaffected by the } \\
\text { fire area (based on visual inspection). Second most abundant stone type used in the monument. } \\
\text { V2 }\end{array}$ \\
V5 & $\begin{array}{c}\text { Compact black stone collected from a severely fire-affected area of the intermediate masonry. } \\
\text { V6 }\end{array}$ \\
V7 & Grey-beige limestone from the new masonry (internal wall), which is a seemingly unaffected by the fire area. \\
V8 & Grey-beige limestone from the historic intermediate masonry, affected by the fire. \\
V9 & Grey-beige limestone from the new masonry (internal wall), affected by the fire. \\
V10 & Limestone, with two distinct zones, one black and one grey-beige, the later similar to V7, unaffected by the \\
fire (based on visual inspection).
\end{tabular}

\section{Petrographic Examination of the Lithotypes}

The petrographic examination was performed on selected samples from different areas of the historic and new masonries. Samples were collected from fire affected and non-affected masonry areas based on visual inspection, which aim to trace the heating impact on the mineralogical and micro-structural characteristics of the different lithotypes.

One of the main building stones used in the historic masonries of 1831 (second most abundant stone type used in the monument) is a clastic calcite sandstone consisting of crystalline and lithic fragments. The sandstone sample V1 was not affected by the fire, based on the visual inspection (Figure 6a). According to the petrographic examination (Figure 6b), the crystalline fragments include quartz $\mathrm{SiO}_{2}$, feldspars [albite $\left(\mathrm{NaAlSi}_{3} \mathrm{O}_{8}\right)$, and microcline $\left(\mathrm{KAlSi}_{3} \mathrm{O}_{8}\right)$ ], calcite $\mathrm{CaCO}_{3}$, muscovite folia [indicative formula: $\mathrm{KAl}_{2}\left(\mathrm{AlSi}_{3} \mathrm{O}_{10}\right)(\mathrm{F}, \mathrm{OH})_{2}$ ], and grains of iron and zirconium oxides/hydroxides. The lithic fraction consists of quartzite, limestone, slate, serpentine, and sub-volcanic rock fragments. The cementing material of the clasts is of sparitic calcite nature. V2 is a sandstone sample of a fire-affected area of the historic masonry (Figure 6c). The petrographic results depict oxidation phenomena of iron-containing minerals. This is macroscopically manifested by the reddening of the sample.

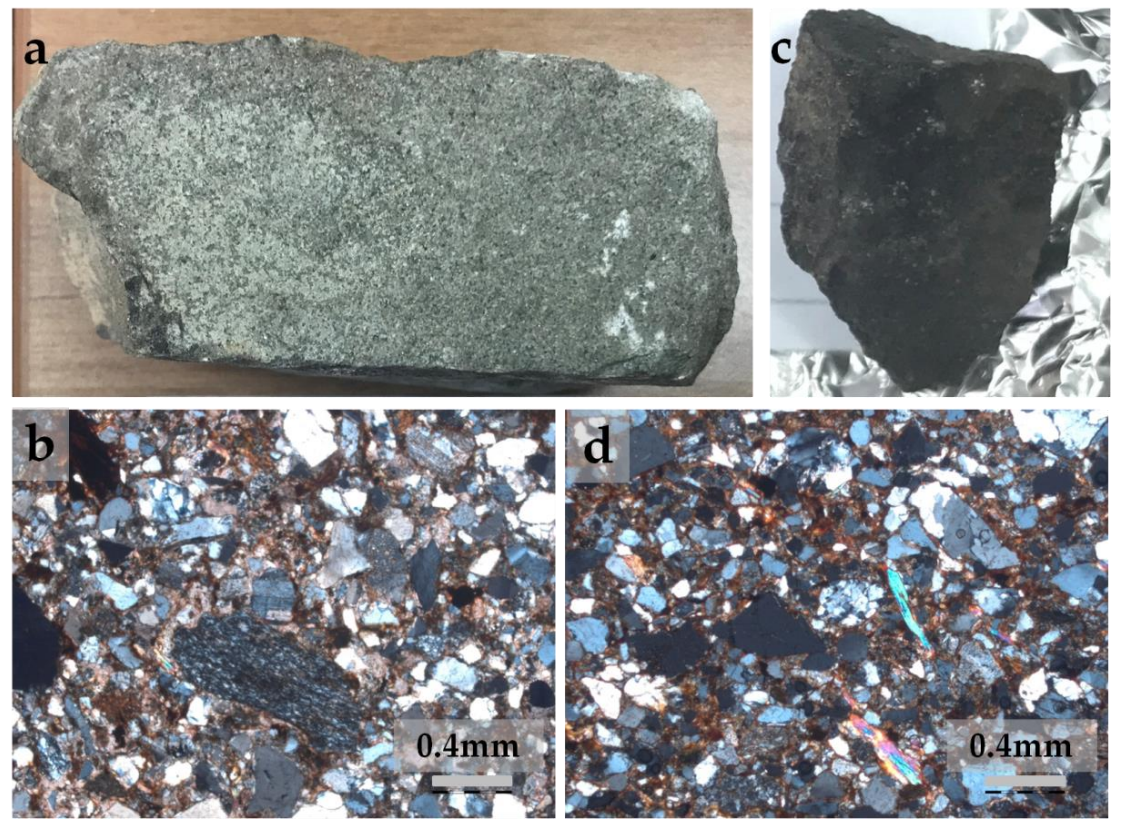

Figure 6. (a) Photograph of sandstone sample V1. (b) The crystalline and lithic fragments of the sandstone are observed. The cementing material is of a sparitic calcite nature (crossed Nicols). (c) Photograph of sandstone sample V2. (d) Oxidation phenomena of iron compounds into the stone mass (crossed Nicols). 
A compact black stone detected on some areas of the historic masonry is a chert (Figure 7a, sample V5). This stone type is sporadically detected in the historic masonries. It was collected from a severely fire-affected area of the intermediate masonry. The stone consists of several zones. In Figure $7 \mathrm{~b}$, three zones are discerned downwards: a) the upper fossiliferous limestone comprising sparitic fossils (mostly foraminiferal species) bound to a micritic mass, b) the intermediate zone of large rhomboid dolomite $\left[\mathrm{CaMg}\left(\mathrm{CO}_{3}\right)_{2}\right]$ crystals, and c) the chert zone consisting of amorphous siliceous material and scattered dolomite crystals. Likewise, in Figure 7c, there is an additional zone where intense diffusion of iron hydroxides is distinguished (dark brown area, Figure 7c). This phenomenon is evident in the fossiliferous limestone zone (Figure 7f). The chert zone is depicted in Figure 7d-e where joints filled with carbonate material and super fine-grained iron pyrite crystals are observed.
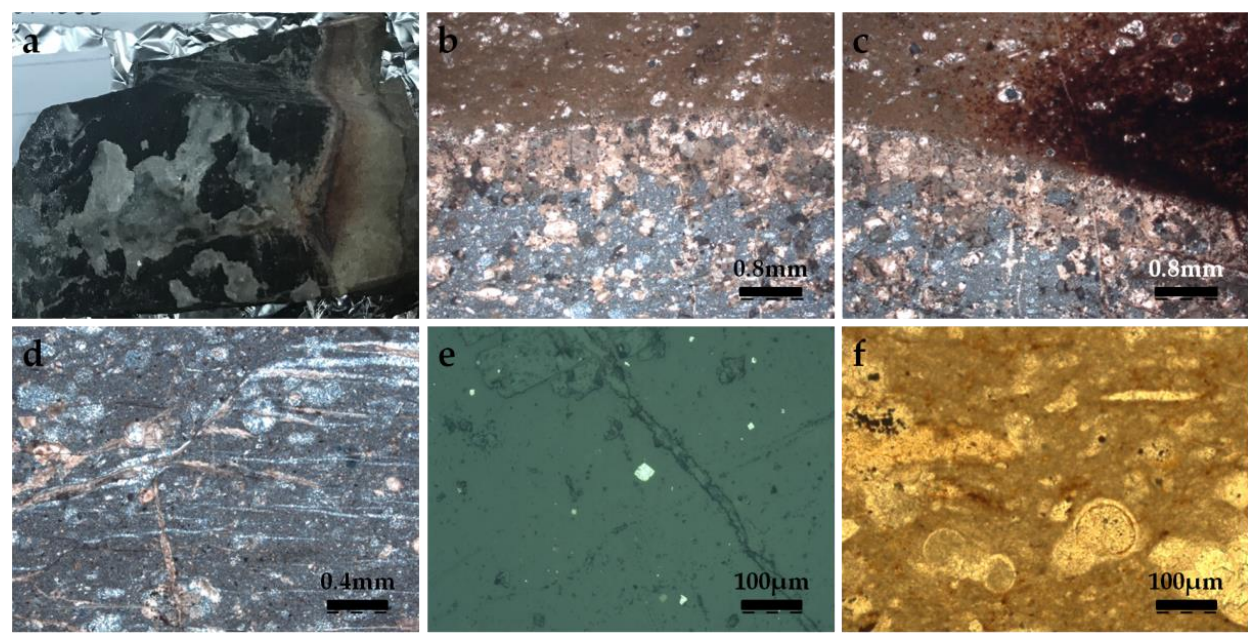

Figure 7. (a) Photograph of sample V5. (b,c) The stone constitutes of three to four zones (crossed Nicols). (d) The chert zone is traversed by joints filled with carbonate content, while super fine-grained iron pyrite is, also, observed (crossed Nicols). (e) The chert zone consists of amorphous siliceous material and scattered iron pyrite crystals, (metallographic microscope, incident light). (f) The fossiliferous limestone zone. The orange hue is attributed to the diffusion of iron hydroxides (parallel Nicols).

The limestone used in the new masonry (internal wall, 1992 reconstruction) is a grey-beige biomicritic limestone (sample V6, visually fire non-affected, Figure 8a). The matrix of the stone is of micritic texture, while traces of fossils and sparitic foraminiferal species are detected inside the stone mass. A great number of joints, filled with secondary calcite, traverse the stone mass (Figure 8b).
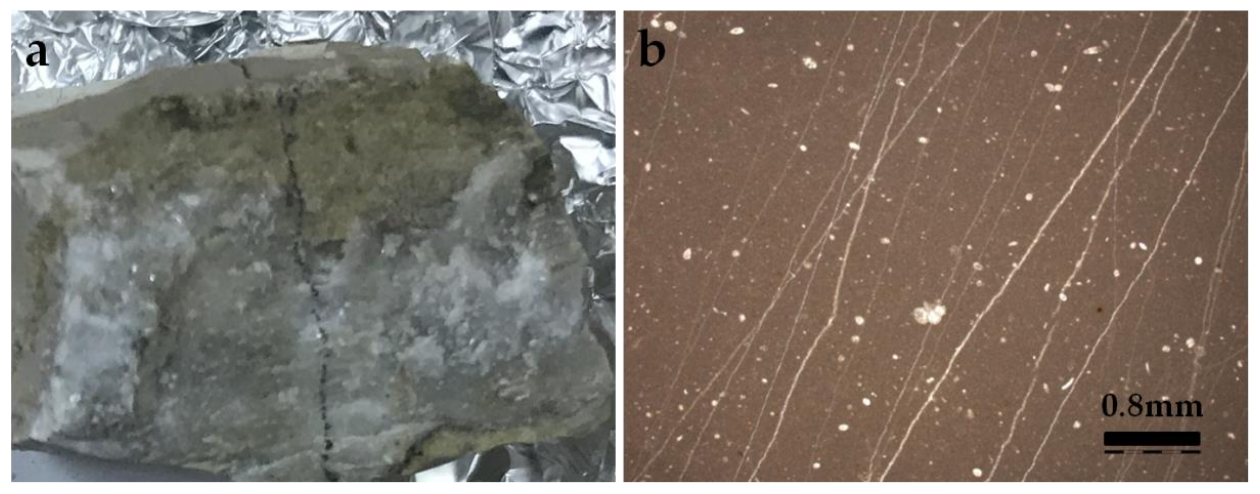

Figure 8. (a) Photograph of limestone sample V6. (b) Grey-beige micritic fossiliferous limestone: the matrix of the stone is of micritic texture, while traces of fossils and sparitic foraminiferal species are detected inside the stone mass. A great number of joints, filled with secondary calcite, traverse the stone mass (parallel Nicols). 
The new masonry is comprised solely of the grey-beige biomicritic limestone (V6). Sample V8 was also collected from the new masonry from an area highly affected by the fire (Figure 9a), as indicated, not only from the location of the sample, but from its pinkish hue as well. This is confirmed by optical microscopy, as V8 presents similar characteristics to sample V6 (Figure 9b). However, the effect of the fire is evident through the widening and rupture of the joints filled with secondary calcite, which is an effect commonly observed in limestones when exposed to extreme temperatures (Figure 9c).
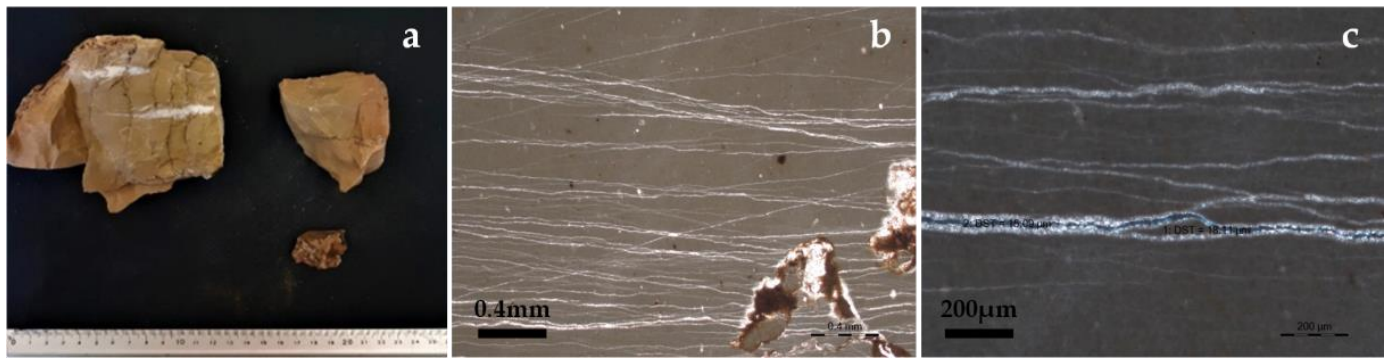

Figure 9. (a) Photograph of fire-effected limestone sample V8. (b) Grey-beige micritic fossiliferous limestone: the matrix of the stone is of micritic texture, while traces of fossils and sparitic foraminiferal species are detected inside the stone mass. A great number of joints, filled with secondary calcite, traverse the stone mass (parallel Nicols). (c) Joint rupture with a width range of 15-18 $\mu \mathrm{m}$ (crossed Nicols).

One of the main construction materials of the historic masonry is a grey-beige micritic fossiliferous limestone. Sample V7 was collected from a severely damaged area of the intermediate masonry, which was clearly affected by the fire (Figure 10a). This damaged historical stone, as expected, presents similar petrographic characteristics to the damaged limestone collected from the new masonry (V8), which confirms macroscopic observations. Joint ruptures are also evident. However, they present a larger width, ranging from $35 \mu \mathrm{m}$ to $65 \mu \mathrm{m}$ (Figure 10b,c).
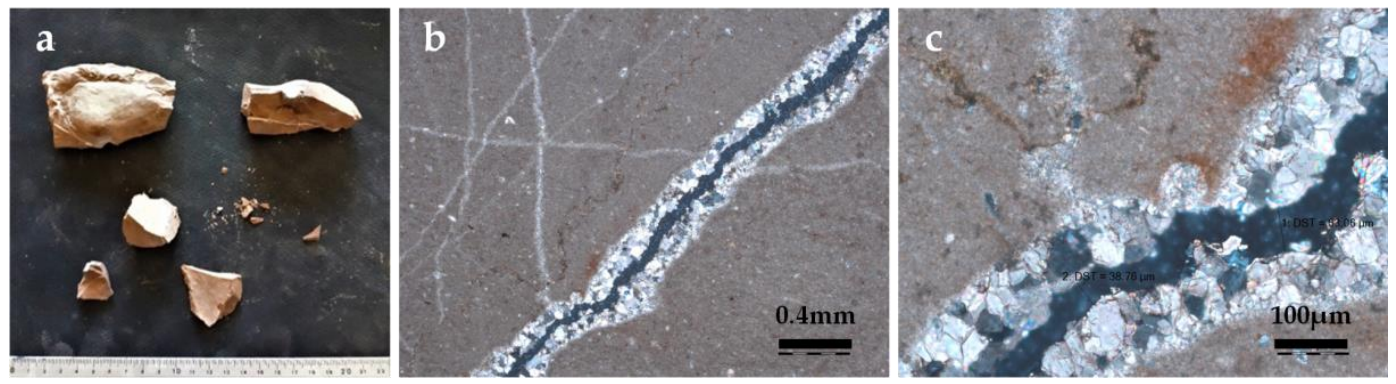

Figure 10. (a) Photograph of fire-effected limestone sample V7. (b) Grey-beige micritic fossiliferous limestone: the matrix of the stone is of micritic texture, while traces of fossils and sparitic foraminiferal species are detected inside the stone mass. A great number of joints, filled with secondary calcite, traverse the stone mass (crossed Nicols). (c) Joint rupture with a width range of 35 to $65 \mu \mathrm{m}$ (crossed Nicols).

In both fire-affected samples of the grey-beige fossiliferous limestone (V8 from new masonry, V7 from historic masonry), stylolites are detected, while iron hydroxides and clay minerals seem to have intruded into their mass. In parallel, as previously mentioned, both samples present a distinct pinkish color. The visual reddening of the stone is attributed to the oxidation of ferrous minerals and the diffusion of iron hydroxides due to the high temperatures developed during the burning event (Figure 9b, Figure 10b,c). Generally, the reddening of limestones due to the oxidation of iron compounds begins at $250-300{ }^{\circ} \mathrm{C}$, but may not be evident before the $400{ }^{\circ} \mathrm{C}$ when the color change becomes more intense $[10,31]$. This discoloration serves as an indication of the minimum temperature range reached during the fire in this area. 
Sample V9 was collected from the historic intermediate masonry, and visual inspection indicated that it was not affected by the fire. Macroscopically, the lithotype presents two distinct zones of different coloration (black and grey-beige, Figure 11a). The matrix of the stone is of micritic texture, while traces of fossils and sparitic foraminiferal species are detected inside the stone mass. A great number of joints, filled with secondary calcite, traverse the stone mass (Figure 11b). The grey-beige biomicritic limestone is accompanied by laminae of a black-grey fossiliferous limestone comprising foraminiferal species of sparitic texture bound to a micritic mass. Oxidized grains of ferrous minerals are, also, detected (Figure 11c).
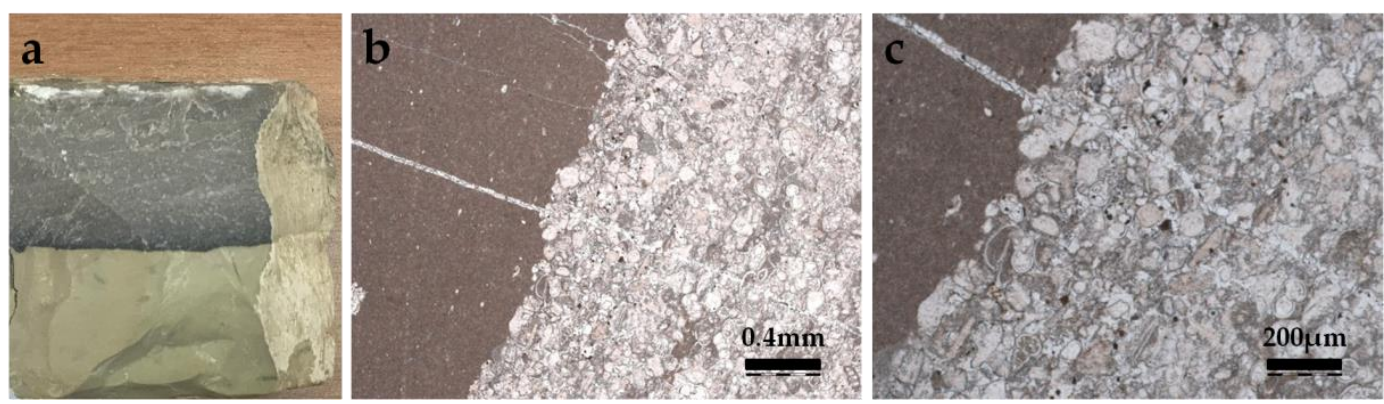

Figure 11. (a) Photograph of limestone sample V9 where two zones are distinct. (b) On the left, the grey-beige micritic fossiliferous limestone zone and, on the right, the grey-black fossiliferous limestone zone, (parallel Nicols). (c) Grains of iron oxides close to the interface of the two zones (parallel Nicols).

Based on visual inspection, a fire-affected sample of the above-described lithotype from the historic intermediate masonry was, also, examined (Figure 12, Sample V10). The visual reddening of the stone is attributed to the oxidation of ferrous minerals and the diffusion of iron hydroxides due to the high temperatures developed during the burning event (Figure 12a-c), as also noticed in samples V8 and V7. The capillary rupture observed in the stone mass constitutes a micro-structural change, as an additional result of the fire impact on the beige-grey limestone zone. The black-grey limestone zone does not present any significant difference from the V9 sample, which was not affected by the fire.
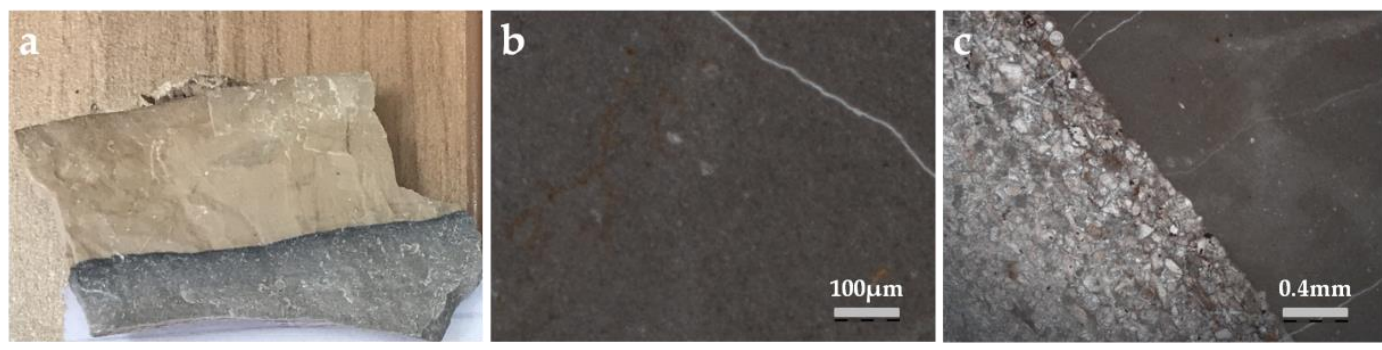

Figure 12. (a) Photograph of fire-affected limestone sample V10. (b) The capillary rupture of some $\mu \mathrm{m}$ width observed in the stone mass constitutes a micro-structural change. The orange hue is due to the diffusion of iron hydroxides and infers the visually observed reddening of the stone (parallel Nicols).

(c) Oxidation of iron compounds due to the high temperature during the fire (parallel Nicols).

Mineralogical Examination of the lithotypes through X-ray Diffraction

Mineralogical examination was conducted only on samples of the main building stones of historic and new masonries, sandstone samples V1, V2, and limestone samples V6, V7, and V8. The lithotypes were pulverized and studied through X-ray diffraction. The results are summarized in Table 2.

Regarding the green sandstone, both unaffected and affected samples (V1 and V2, respectively) present similar mineralogical composition, with quartz as the principal mineralogical component and calcite, albite, muscovite, and chlorite as accessory mineralogical components. However, in sample V1, 
microcline is detected, while, in sample V2, it is not detected. This is in accordance to other studies that have demonstrated that microcline does decrease as the temperature of the stone increases [32].

Table 2. XRD analysis of stone samples.

\begin{tabular}{ccc}
\hline Sample Code & \multicolumn{2}{c}{ Mineralogical Composition (XRD Analysis) } \\
\hline & Principal mineralogical components & Accessory mineralogical components \\
\cline { 2 - 3 } V1 & Quartz & calcite, albite, microcline, muscovite, chlorite \\
V2 & Quartz & calcite, albite, muscovite, and chlorite \\
V6 & Calcite & quartz \\
V7 & Calcite & quartz \\
V8 & Calcite & quartz \\
\hline
\end{tabular}

Regarding the beige-grey limestone, the only lithotype used in the new masonry and the most dominant in the historic ones, no alterations are noticed in relation to mineralogical composition between the unaffected (V6) and the affected by the fire samples, from both the new (V8) and the historic masonry (V7). Thus, the beige-gray limestone presents calcite as its principal mineralogical component and quartz as an accessory.

Compositional analysis of stone samples through simultaneous thermal analysis (TG/DTA)

The previously mentioned stone samples (V1, V2, V6-V8) were also examined through simultaneous thermal analysis, which aim to reveal modifications in their chemical composition due to the fire. The results are presented in Table 3, which report the mass loss (\%) measured in specific temperature ranges.

Table 3. TG results of stone samples.

\begin{tabular}{ccccc}
\hline \multirow{2}{*}{ Stone Sample Code } & \multicolumn{4}{c}{ Mass Loss (\%) per Temperature Range $\left({ }^{\circ} \mathbf{C}\right)$} \\
\cline { 2 - 5 } & $\mathbf{< 1 2 0}{ }^{\circ} \mathbf{C}$ & $\mathbf{1 2 0 - 2 0 0}{ }^{\circ} \mathbf{C}$ & $\mathbf{2 0 0 - 6 0 0 ~}{ }^{\circ} \mathbf{C}$ & $>\mathbf{6 0 0}{ }^{\circ} \mathbf{C}$ \\
\hline V1 & 0.20 & 0.04 & 1.19 & 5.44 \\
V2 & 1.11 & 0.13 & 1.04 & 1.64 \\
V6 & 0.14 & 0.03 & 0.23 & 39.30 \\
V7 & 0.17 & 0.02 & 0.36 & 38.99 \\
V8 & 0.12 & 0.01 & 0.16 & 38.92 \\
\hline
\end{tabular}

The unaffected sandstone sample V1 presents distinct differences in relation to the affected ones by the fire sandstone sample V2. In particular, sample V2 presents a higher amount of physically bound water in comparison to V1 (increased mass loss in temperature range $30-120^{\circ} \mathrm{C}$ ), which indicates a modification in the microstructure that increases water uptake from the environment after the effect of the fire. In addition, the mass loss above $600{ }^{\circ} \mathrm{C}$, which is connected to the decomposition of carbonate compounds, is also distinctly different. The affected sample V2 presents a much lower carbonate content indicating that the calcite binding material of the matrix of the sandstone was reduced due to the fire, which confirms OM observations. It should be noted that, in the DTA curve, the distinct endothermic peak connected to quartz transition from $\alpha \rightarrow \beta$ is noticed at $\sim 575{ }^{\circ} \mathrm{C}$. Although the carbonate compounds' decomposition endothermic peak is clear in the unaffected sample $\left(\sim 770{ }^{\circ} \mathrm{C}\right)$, it is not discernable in the fire-affected sample V2.

The beige-grey limestone of the historic and new masonries (V6-V8) seems to be unaffected by the fire in relation to its chemical composition. All samples present similar mass losses in all temperature ranges, which is independent of the fire effect. This confirms XRD results as well. The decomposition temperature of the carbonate compounds was detected above $800^{\circ} \mathrm{C}$.

Total Immersion Results on Stone Lithotypes

Total immersion was conducted on the stone samples, which aim to evaluate their porosity (\%) accessible to water through total immersion. Water Absorption Capacity (WAC\%) was calculated, 
while the apparent density of the samples was calculated as well. The results are summarized in Table 4 .

Table 4. Total water immersion tests results - stones.

\begin{tabular}{|c|c|c|c|}
\hline Stone Sample Code & Porosity (\%) & Bulk Density $\left(\mathrm{g} / \mathrm{cm}^{3}\right)$ & W.A.C. $(\%)$ \\
\hline V1 & 3.7 & 2.4 & 1.5 \\
\hline V2 & 6.1 & 2.2 & 2.8 \\
\hline V6 & 2.6 & 2.3 & 1.1 \\
\hline V7 & 2.9 & 2.1 & 1.4 \\
\hline V8 & 2.1 & 2.3 & 0.9 \\
\hline
\end{tabular}

The characteristics of the unaffected and fire-affected sandstone samples display diverse values, which confirm a visual inspection observation regarding their state. In particular, the affected sample, V2, presented a higher porosity ( $6 \%$ in relation to $3.7 \%$ ), which indicates the creation of pores and micro-cracks. This alteration is consistent with the different mass loss values demonstrated by TG measurements in temperatures above $600{ }^{\circ} \mathrm{C}$. Bulk density is slightly decreased from $2.4 \mathrm{~g} / \mathrm{cm}^{3}$ to $2.2 \mathrm{~g} / \mathrm{cm}^{3}$ due to the porosity increase and transformation, which take place on a mineralogical and chemical level. The water absorption capacity of the sandstone increases after the fire-event, as expected. The later statement is also evident through the higher mass loss detected for the affected stone through TG attributed to physically bound water (mass loss $<120^{\circ} \mathrm{C}$ ).

The beige-grey limestone, on the other hand, seems not to be affected in relation to its physical characteristics, which is also noticed in the mineralogical and thermal analysis results. Porosity of the unaffected limestone (V6) and the fire-affected one (V8), from the new masonry, is very close $(2.6 \%$ and $2.1 \%$, respectively). Bulk density values are identical $\left(2.3 \mathrm{~g} / \mathrm{cm}^{3}\right)$, while water absorption capacity of the affected and non-affected samples are also extremely close $(1.1 \%, 0.9 \%)$. The fire-affected limestone sample from the historic intermediate masonry (V7) also presents similar values to the previously mentioned samples, as expected since they are of the same lithotype. Its slightly higher porosity $(2.9 \%)$ could be attributed to ageing processes in addition to the fire effect. The same is true for the slightly lower bulk density that it exhibits $\left(2.1 \mathrm{~g} / \mathrm{cm}^{3}\right)$ in relation to the new masonry fire-affected limestone V8 $\left(2.3 \mathrm{~g} / \mathrm{cm}^{3}\right)$, as well as the slightly higher water absorption capacity it presents $(1.4 \%$ in relation to $0.9 \%)$.

\subsubsection{Investigation of the Mortars}

Mortar samples were collected from both the historic intermediate masonry and the new masonry. The mortar samples' description, along with characteristic digital microscopy images depicting their surface texture, are presented in Table 5. 
Table 5. Description of the selected mortar samples from the cells' quarter.

\begin{tabular}{|c|c|c|}
\hline Mortar Sample Code & Sample Description & DM Image \\
\hline Vm1 & $\begin{array}{l}\text { Structural soft mortar of clay texture and } \\
\text { light-orange hue with blackened external surface due } \\
\text { to the smoke deposition-upper part of the historical } \\
\text { intermediate masonry (above } 2 \mathrm{~m} \text { ). }\end{array}$ & \\
\hline $\operatorname{Vm} 2$ & $\begin{array}{l}\text { Joint mortar of cementitious texture from a severely } \\
\text { fire-affected area from the middle part of the new } \\
\text { masonry }(\sim 1.5 \mathrm{~m}) .\end{array}$ & \\
\hline Vm3 & $\begin{array}{l}\text { Structural soft mortar of clay texture and } \\
\text { dark-orange hue from the upper part of the historical } \\
\text { intermediate masonry (above } 2 \mathrm{~m} \text { ). }\end{array}$ & \\
\hline $\operatorname{Vm} 4$ & $\begin{array}{l}\text { Structural soft mortar of clay texture and yellow hue } \\
\text { from the upper part of the historical intermediate } \\
\text { masonry (above } 2 \mathrm{~m} \text { ). }\end{array}$ & \\
\hline Vm5 & $\begin{array}{l}\text { Structural soft mortar of clay texture and yellow hue } \\
\text { from the upper part of the historical intermediate } \\
\text { masonry (above } 2 \mathrm{~m} \text { ). }\end{array}$ & \\
\hline Vm6 & $\begin{array}{l}\text { In-depth mortar of mixed cementitious and clay } \\
\text { texture from a severely fire-affected area at the lower } \\
\text { part of the historical intermediate masonry }(<1 \mathrm{~m}) \text {. }\end{array}$ & \\
\hline Vm7 & $\begin{array}{l}\text { Joint mortar of cementitious texture from a severely } \\
\text { fire-affected area with blackened external surface due } \\
\text { to smoke deposition - lower part of the historical } \\
\text { intermediate masonry (same sampling area with } \\
\qquad \mathrm{Vm} 6,<1 \mathrm{~m})\end{array}$ & \\
\hline
\end{tabular}


Table 5. Cont.

\begin{tabular}{|c|c|c|}
\hline Mortar Sample Code & Sample Description & DM Image \\
\hline Vm8 & $\begin{array}{l}\text { Structural soft mortar of clay texture and yellow hue } \\
\text { from the upper part of the historical intermediate } \\
\text { masonry (above } 2 \mathrm{~m} \text { ). }\end{array}$ & \\
\hline Vm9 & $\begin{array}{l}\text { Joint mortar of cementitious texture and pinkish hue } \\
\text { from a severely fire-affected area at the lower part of } \\
\text { the new masonry }(<1 \mathrm{~m}) \text {. }\end{array}$ & \\
\hline
\end{tabular}

\subsubsection{Mineralogical Examination of the Mortar Samples through X-Ray Diffraction}

XRD results are presented in Table 6 and show that the principal mineralogical component phase of the clay textured mortars $(\mathrm{Vm} 1, \mathrm{Vm} 3, \mathrm{Vm} 4, \mathrm{Vm} 5$, and $\mathrm{Vm} 8)$ is quartz. The previously mentioned samples all display an adequate presence of calcite and muscovite. Chlorite is also detected in samples $\mathrm{Vm} 4, \mathrm{Vm} 5$, and $\mathrm{Vm} 8$, while microcline is detected in Vm5 and Vm8. In Vm5, the presence of microcline is increased. Albite is detected with a high presence in samples $\operatorname{Vm} 1$ and $\mathrm{Vm} 5$ and with a lower presence in sample Vm3.

Table 6. XRD analysis of mortars' samples.

\begin{tabular}{ccc}
\hline Sample Code & \multicolumn{2}{c}{ Mineralogical Composition (XRD Analysis) } \\
\hline & Principal mineralogical components & Accessory mineralogical components \\
\cline { 2 - 3 } Vm1 & Quartz & Calcite, albite, muscovite \\
Vm2 & Calcite & Quartz, albite \\
$V m 3$ & Quartz & Calcite, muscovite, albite \\
$\operatorname{Vm} 4$ & Quartz & Calcite, muscovite, chlorite \\
$\operatorname{Vm} 5$ & Quartz & Muscovite \\
$\operatorname{Vm} 6$ & Quartz, calcite & albite \\
$\operatorname{Vm} 7$ & Calcite, quartz & Microcline, albite, calcite, muscovite, chlorite, \\
$\operatorname{Vm} 8$ & Quartz & calcite, muscovite, microcline, chlorite \\
$\operatorname{Vm} 9$ & Calcite, quartz & - \\
\hline
\end{tabular}

Samples Vm2, Vm6, Vm7, and Vm9 are fire-affected mortars of a cementitious texture. $\mathrm{Vm} 2$ presents calcite as a principal mineralogical component and quartz and albite as accessory minerals. Vm6, which is of a mixed clay-cementitious texture, presents quartz and calcite as the main mineralogical components, while muscovite is also present. Vm7 presents calcite and quartz as principal mineralogical components, and albite is also detected. Vm 9 from the new masonry and an area that was severely affected by the fire presents only calcite and quartz as mineralogical components, with no secondary accessory minerals. It is thus evident, that all cementitious textured mortars present a high amount of calcite in relation to other minerals. Contrary to the cementitious textured mortars, the clayey textured mortars present quartz as principal mineralogical component, except for Vm6, which presents both quartz and calcite in high abundance, thus confirming to a certain extent the DM microscopy results regarding this sample's mixed texture (Table 5).

\subsubsection{Compositional Analysis of Mortar Samples through Simultaneous Thermal Analysis (TG/DTA)}

Thermal analysis results are presented in Table 7, where the weight loss percentages per temperature range are presented. Each temperature range corresponds to different processes: (i) the 
mass loss observed in the $<120^{\circ} \mathrm{C}$ temperature range is due to the loss of physically bound water $\left(\mathrm{H}_{2} \mathrm{O}_{\mathrm{PBW}}\right)$, (ii) the mass loss detected in the range $120-200^{\circ} \mathrm{C}$ is attributed to the loss of the crystalline water of salts (e.g., gypsum), (iii) the mass loss observed in the temperature range $200-600{ }^{\circ} \mathrm{C}$ is attributed to chemically-bound water $\left(\mathrm{H}_{2} \mathrm{O}_{\mathrm{SWB}}\right)$ (e.g., dehydroxylation of clay minerals, dehydration of aluminosilicates, or calcium aluminosilicate phases etc.), (iv) the mass loss detected in the range $>600{ }^{\circ} \mathrm{C}$ is attributed to the decomposition of carbonates and consequent $\mathrm{CO}_{2}$ loss [33]. The inverse hydraulicity index is calculated as the ratio $\mathrm{CO}_{2} / \mathrm{H}_{2} \mathrm{O}_{\mathrm{SWB}}$ and is widely used in order to evaluate the hydraulicity of a mortar (lower inverse hydraulicity indexes are indicative of more hydraulic mortars) [34].

Table 7. TG results of mortars' samples.

\begin{tabular}{|c|c|c|c|c|c|}
\hline \multirow{2}{*}{ Mortar Sample Code } & \multicolumn{4}{|c|}{ Mass Loss $(\%)$ per Temperature Range $\left({ }^{\circ} \mathrm{C}\right)$} & \multirow{2}{*}{$\mathrm{CO}_{2} / \mathrm{H}_{2} \mathrm{O}_{\mathrm{CBW}}$} \\
\hline & $<120^{\circ} \mathrm{C}$ & $120-200{ }^{\circ} \mathrm{C}$ & $200-600{ }^{\circ} \mathrm{C}$ & $>600{ }^{\circ} \mathrm{C}$ & \\
\hline Vm1 & 1.17 & 0.44 & 4.02 & 7.96 & 1.98 \\
\hline $\mathrm{Vm} 2$ & 0.54 & 0.22 & 1.49 & 20.19 & 13.55 \\
\hline $\mathrm{Vm} 3$ & 1.00 & 0.25 & 2.84 & 8.32 & 2.93 \\
\hline Vm4 & 1.17 & 0.45 & 4.32 & 8.41 & 1.95 \\
\hline Vm5 & 1.23 & 0.43 & 3.81 & 7.33 & 1.92 \\
\hline Vm6 & 1.23 & 0.27 & 3.31 & 14.45 & 4.37 \\
\hline $\mathrm{Vm} 7$ & 1.37 & 0.51 & 2.99 & 20.93 & 7.00 \\
\hline Vm8 & 1.28 & 0.47 & 4.04 & 6.62 & 1.64 \\
\hline Vm9 & 1.50 & 0.62 & 3.11 & 18.57 & 5.97 \\
\hline
\end{tabular}

All samples present mass losses attributed to physically bound water between $1 \%$ and $1.5 \%$, except for the cementitious textured mortar $\mathrm{Vm} 2$, which presents $0.54 \%$. They also present low mass losses in the temperature range of 120 to $200^{\circ} \mathrm{C}$, which indicates extremely low percentages of crystalline water bound to hygroscopic salts. Chemically bound water presents dispersion among the mortar samples ranging from $1.49 \%$ to $3.11 \%$ for the cementitious-textured mortars, and $2.84 \%$ to $4.32 \%$ for the clayey textured mortars. Sample Vm6, which is of a mixed texture, presents a chemically-bound water percentage higher than the cementitious-textured mortars and within the range of the clayey textured mortars. All cementitious-textured mortars present relatively high mass losses attributed to the loss of $\mathrm{CO}_{2}$ due to the decomposition of carbonate materials (ranging from $18.57 \%$ to $20.93 \%$ ), while all clayey textured mortars present lower mass losses in the previously mentioned range (ranging from $6.62 \%$ to $8.41 \%$ ). Sample Vm6, of a mixed texture, presents a $\mathrm{CO}_{2}$ mass loss value intermediate of the cementitious and clayey textured mortars. The mass loss values attributed to $\mathrm{CO}_{2}$ loss also indicate the siliceous and mixed carbonate and siliceous nature of the aggregates of all mortars investigated.

However, the $\mathrm{CO}_{2} / \mathrm{H}_{2} \mathrm{O}_{\mathrm{CBW}}$ ratio is used to determine whether a mortar is of hydraulic nature. In the present study, it is used, in addition to the mass loss attributed to the decomposition of carbonates above $600{ }^{\circ} \mathrm{C}$, to discriminate clay mortars from cement mortars aimed to ascertain their nature (Figure 13). It is clear that the "clayey" mortars (Vm1, Vm3, Vm4, Vm5 and Vm8) are all grouped in a very tight area, while the "cement textured" mortars are also grouped, but with a wider distribution. The mixed-textured sample, Vm6, falls between the two groups, in closer vicinity to the cement textured mortars. The thermal analysis results indicate that there are two types of mortar in the masonry, namely clay mortars and cement-based mortars. The thermal analysis results, in combination with the mineralogical analysis, indicate relatively high carbonation of the cement-based mortars, especially in the case of $\mathrm{Vm} 2$, which was located in the middle part of the new masonry. 


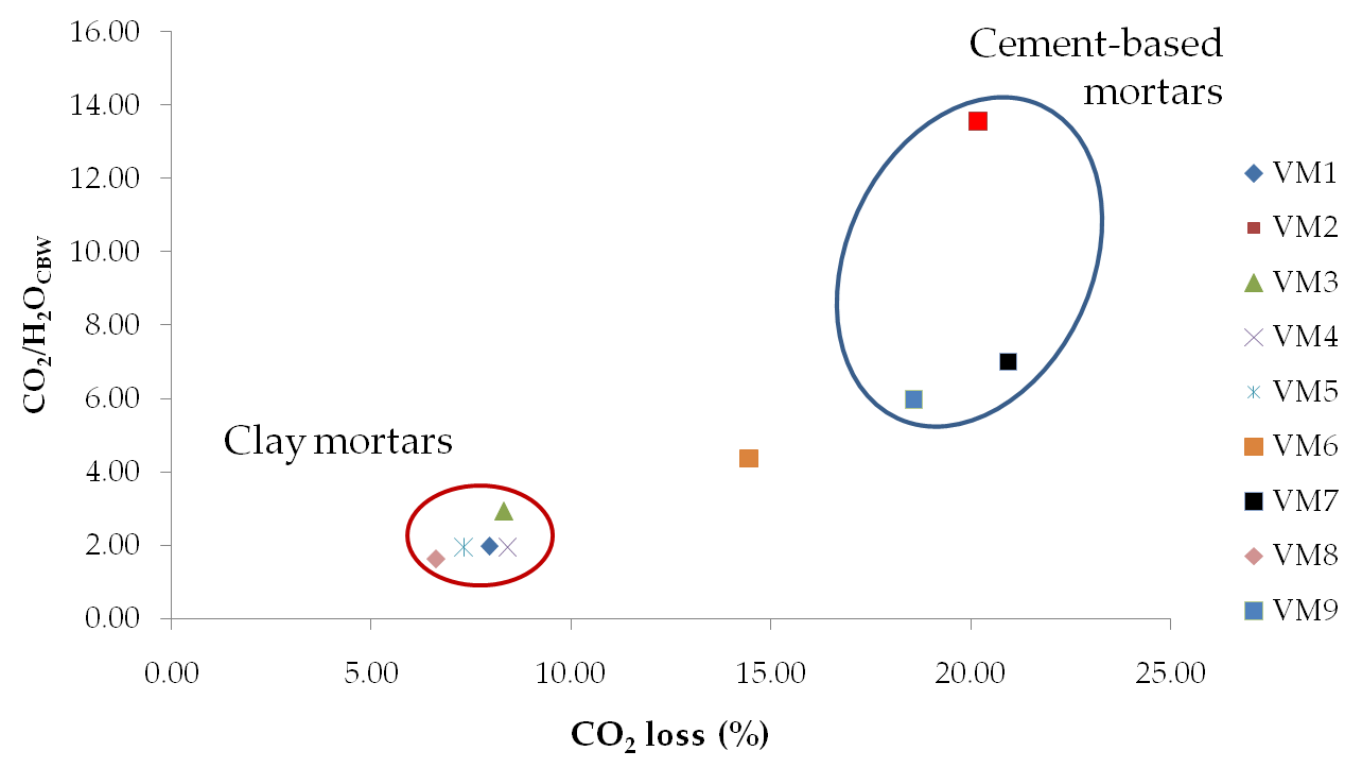

Figure 13. Correlation of $\mathrm{CO}_{2}$ and the $\mathrm{CO}_{2} / \mathrm{H}_{2} \mathrm{O}_{\mathrm{CBW}}$ ratio. The clay mortar group and cement-based mortar group are indicated.

\subsubsection{Total Immersion Results on Mortar Samples}

Total water immersion tests were conducted on selected mortar samples. Since it was not possible to conduct these measurements on all mortar samples, due to their poor state of preservation and consequent dissolution in water, measurements were only conducted on samples Vm2, Vm9 (cement-based mortars), and sample Vm4 (clay mortar). The results are summarized in the following table (Table 8).

Table 8. Total water immersion tests results - mortars.

\begin{tabular}{|c|c|c|c|}
\hline Mortar Sample Code & Porosity (\%) & Bulk Density $\left(\mathrm{g} / \mathrm{cm}^{3}\right)$ & W.A.C. (\%) \\
\hline $\mathrm{Vm} 2$ & 17.00 & 1.45 & 14.33 \\
\hline $\mathrm{Vm} 4$ & 31.18 & 1.63 & 25.38 \\
\hline Vm9 & 22.00 & 1.34 & 17.15 \\
\hline
\end{tabular}

The clay mortar (V4) presents the highest porosity accessible to water $(31.18 \%)$, as expected for a mortar of this category. The cement mortars present relatively high porosity values of $17 \%$ and $22 \%$ for samples $\mathrm{Vm} 2$ and $\mathrm{Vm} 9$, respectively. However, this is distinctly lower than the clay mortar. Their porosity values, in addition to thermal analysis results, confirm a high level of carbonation, which is probably due to the fire effect and the consequent microstructure alteration. The water absorption capacity of the clay mortar is the highest among the examined samples $(25.38 \%)$, while the cement mortars present similar values $(14.33 \%$ and $17.15 \%)$. Regarding bulk density, the cement mortars $\mathrm{Vm} 2$ and $\mathrm{Vm} 9$ present values very low for cement mortars, which is clearly due to their poor state of preservation $\left(1.45 \mathrm{~g} / \mathrm{cm}^{3}\right.$ and $\left.1.34 \mathrm{~g} / \mathrm{cm}^{3}\right)$ because of the fire effect. This result can also be attributed to a mixed cement-lime composition of the cement-based mortars (which present lower bulk densities than cement mortars) without diminishing the destructive role of the fire event. $\mathrm{Vm} \mathrm{4}$, which is the clay mortar examined, presents a bulk density of $1.63 \mathrm{~g} / \mathrm{cm}^{3}$. This is an intermediate value for historic mortars.

\subsection{SHR Results}

AREA 1 (Figure 14) is the area left of the entrance to the Monastery and is mainly comprised of the beige-grey limestone and the sandstone. The results from the SHR measurements are presented in 
Table 9. As already mentioned, this part of the masonry belongs to the historical phase of 1831-1838 and is seemingly unaffected by the fire. The highest Rebound value corresponds to the black chert, which is found as an inclusion inside the limestone in this area. The grey-beige limestone presents higher surface hardness index values than the sandstone examined.

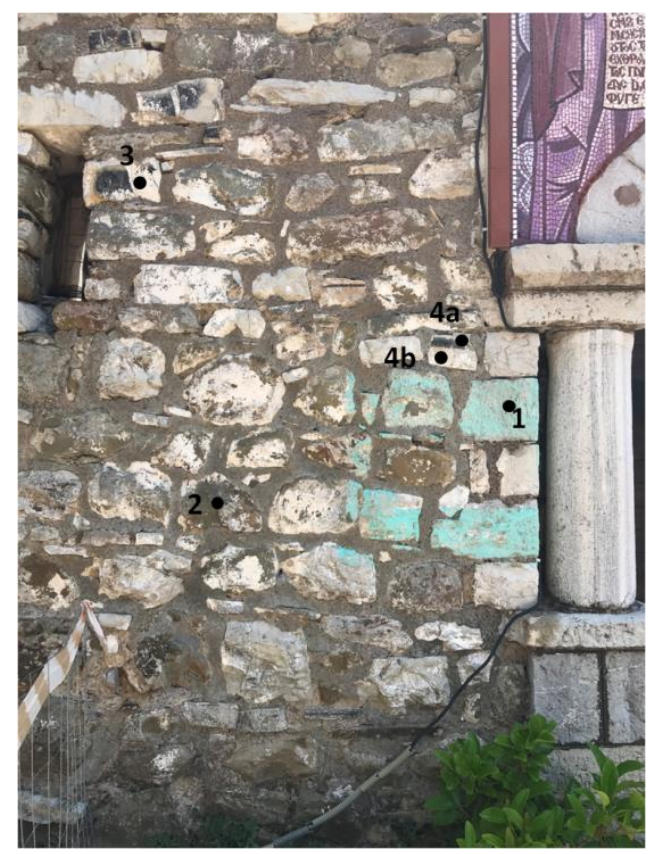

Figure 14. AREA 1: The exterior of the external masonry, on the left of the entrance to the monastic cells quarter (historic masonry, western façade). Bullets and numbering indicate where the SHR measurements were performed.

Table 9. SHR values from the AREA 1 (see Figure 14).

\begin{tabular}{cccc}
\hline & \multicolumn{2}{c}{ AREA 1 } & \\
\hline Type of Lithotype & $\mathbf{R m}$ & Rmedian & COV\% \\
\hline 1. Beige - grey limestone & $51.04 \pm 1.97$ & $50.00 \pm 1.25$ & 7.6 \\
2. Sandstone & $43.96 \pm 3.14$ & $44.00 \pm 2.25$ & 7.14 \\
3. Black chert inclusion & $56.92 \pm 4.72$ & $58.50 \pm 5.3$ & 8.30 \\
4. Beige - grey limestone & & & \\
4a. Black calcite vein & $47.58 \pm 14.20$ & $42.75 \pm 7.75$ & 29.84 \\
4b. Beige-grey limestone & $50.08 \pm 5.22$ & $49.50 \pm 3.50$ & 10.42 \\
\hline
\end{tabular}

The eastern façade of the intermediate historic masonry (AREA 2) was investigated after being divided per height in two areas: below $50 \mathrm{~cm}$ and above $1 \mathrm{~m}$ (Figures 15a and 15b). This area was completely affected by the fire burning and presents the most intense deterioration patterns, such as extreme scaling of the beige-grey limestone and exfoliation of the sandstones. The black chert was also examined (Figure 15a, sub-area 2). This latter type of stone seems macroscopically less affected by the fire, but presents a SHR value decrease close to $50 \%$ compared to the value from the fire unaffected masonry (Figure 14-AREA 1, sub-area 3). In both zones, the beige-grey limestone presents the lower Rebound values compared to the green sandstone, which indicates a higher deterioration level due to the fire event (Table 10). 

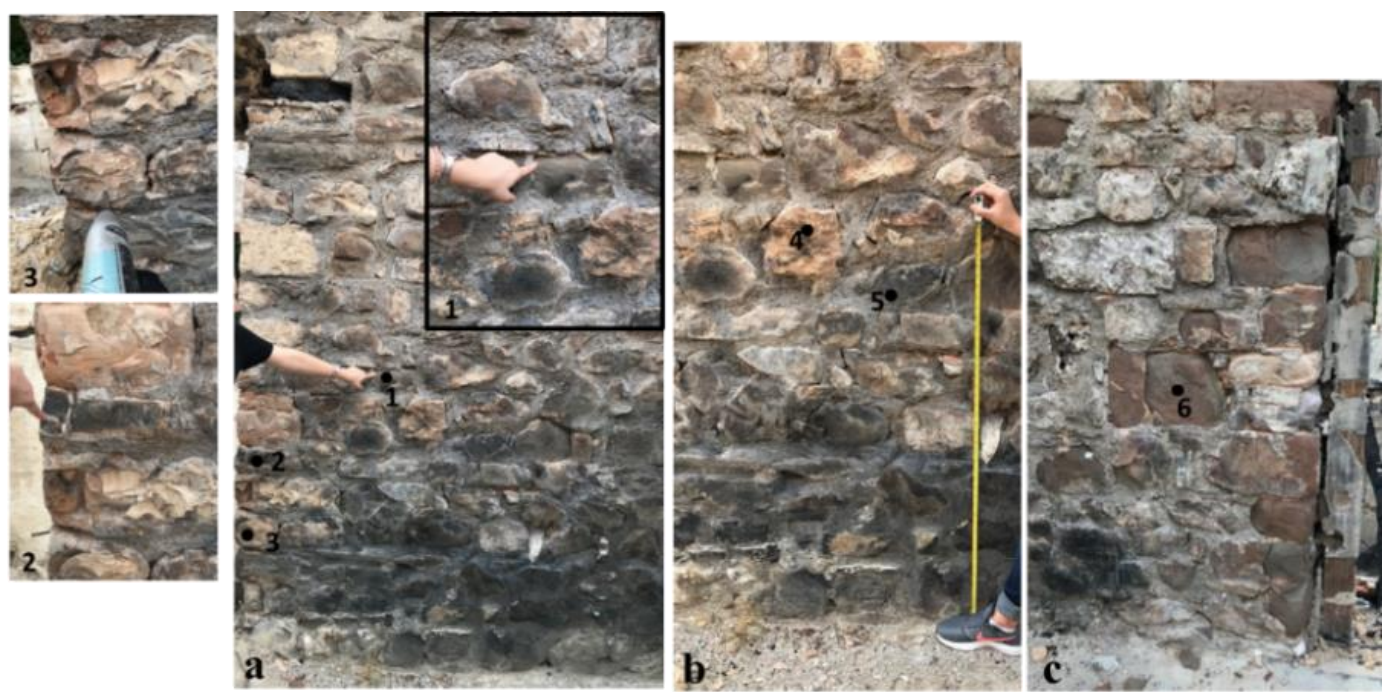

Figure 15. AREA 2: Intermediate masonry of the cells quarter (historic wall, eastern façade). Bullets and numbering indicate the areas where the SHR measurements were performed: (a) Three sub-areas examined below $50 \mathrm{~cm}$. (b) Two sub-areas examined above $1 \mathrm{~m}$. (c) The examined fire affected sandstone. Bullets and numbering indicate where the SHR measurements were performed.

Table 10. SHR values from the AREA 2 (see Figure 15).

\begin{tabular}{cccc}
\hline & AREA 2- Under 50 cm Height & \\
\hline Type of Lithotype & Rm & Rmedian & COV\% \\
\hline 1. Sandstone & $42.14 \pm 2.67$ & $42.00 \pm 3.00$ & 6.34 \\
2. Black chert & $30.00 \pm 3.96$ & $30.50 \pm 4.50$ & 13.19 \\
3. Beige-grey limestone & $15.79 \pm 1.95$ & $16.25 \pm 2.00$ & 12.38 \\
\hline & AREA 2 -above $\mathbf{1}$ $\mathbf{~ h e i g h t ~}$ & \\
\hline 4. Beige-grey limestone & $17.14 \pm 1.52$ & $17.00 \pm 1.10$ & 8.87 \\
5. Sandstone & $36.87 \pm 2.54$ & $36.90 \pm 2.5$ & 6.88 \\
\hline & Sub-Area 6 & \\
\hline 6. Sandstone & $25.83 \pm 5.29$ & 20.46 \\
\hline
\end{tabular}

The lower value for the sandstone, from all examined areas, was recorded in the intermediate masonry (Figure 15c, sub-area 6), in an area severely affected by the fire. This higher alteration of the sandstone surface in this area may indicate a higher exposure of this part of the masonry at the fire.

The plastered south-western façade of the intermediate masonry (AREA 3) had also been impacted by the fire (Figure 16). The three-layer plaster has a total width that varies from $3.5 \mathrm{~cm}$ (thicker layer in the western side) to $2 \mathrm{~cm}$ (thinner layer on the southern side). The SHR tests were performed in both sides of the stone blocks (west and south sides) and after the full removal of the overlying plaster. The overall results are presented in Table 11. During the procedure, the higher Rebound values were measured at the points of the stone that were covered by the thicker plaster layer on the western stone side. This may indicate an increased protective function of the thicker plaster layer on the masonry. The reduction in the SHR index for the beige-grey limestone is lower compared to the eastern façade of the intermediate masonry, which was un-plastered, since it used to be the external wall of the cells' rooms (see Table 10). 

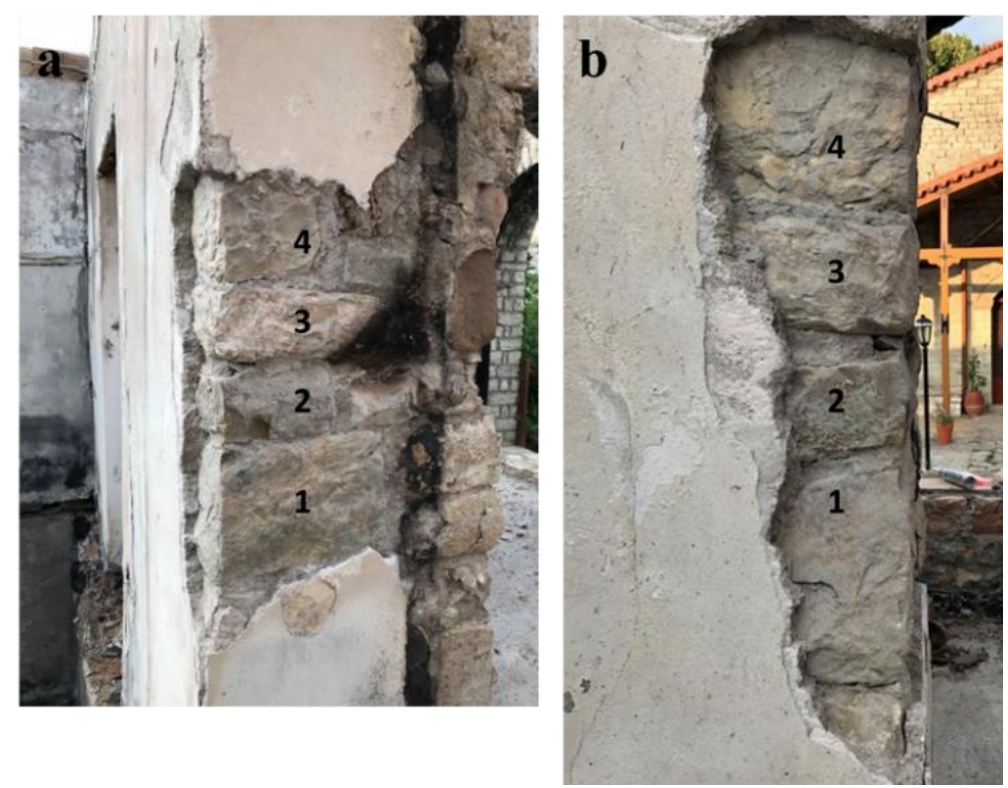

Figure 16. AREA 3: South-Western façade of the intermediate masonry. The area was examined after the plaster's removal. (a) South façade of the intermediate masonry. (b) Western façade of the intermediate masonry. Numbering indicates the corner-stones examined by SHR from south to west.

Table 11. SHR values from AREA 3 (see Figure 16).

\begin{tabular}{cccc}
\hline \multicolumn{4}{c}{ AREA3 } \\
\hline Type of Lithotype & $\mathbf{R m}$ & Rmedian & COV\% \\
\hline 1. Sandstone & $47.35 \pm 1.33$ & $47.00 \pm 0.85$ & 2.82 \\
2. Sandstone & $34.57 \pm 4.02$ & $34.50 \pm 4.50$ & 11.64 \\
3. Beige- grey limestone & $42.5 \pm 5.62$ & $43.00 \pm 5.25$ & 13.22 \\
4. Beige-grey limestone & $46.16 \pm 4.69$ & $44.50 \pm 5.30$ & 10.17 \\
\hline
\end{tabular}

In order to further estimate the fire impact on the grey compact limestone, a wall pillar from the new masonry (northern façade, from interior to exterior) was examined (Figures 2 and 3f).

This part of the masonry was constructed between the years 1992 to 2014. The 2017's fire event left intact the exterior façade of the masonry (eastern façade, the one facing the courtyard) while intense fire effects are observed at the interior (western) façade, such as discoloration, scaling, and detachments. The area under examination, depicted in Figure 17, was divided into zones for the SHR measurements to be carried out. a) a fire-affected zone (FAZ), according to visual inspection with a total length of approximately $8 \mathrm{~cm}$, where a burnt front, facing west (interior façade), and a burnt zone, facing north, are evident. b) A potentially fire unaffected zone (FUZ), which was further examined both in the middle and in the outer side of each stone block, and c) an in-between zone of $\sim 10 \mathrm{~cm}$ length. The total width of the wall is $51 \mathrm{~cm}$, while the SHR measurements were conducted in a height of six stone arrays (total height around $60 \mathrm{~cm}$ ). The results are presented in Table 12. A progressive decline in the Rebound values is observed. The most affected area i.e. the FAZ burnt front presents an approximate loss of SHR hardness value of $52 \%-58 \%$ compared to the macroscopically perceived sound zones. The SHR values of the beige-grey limestone, which are visually perceived as fire unaffected zones, are similar to the ones received from the fire unaffected AREA 1 (Figure 14, Table 9). 


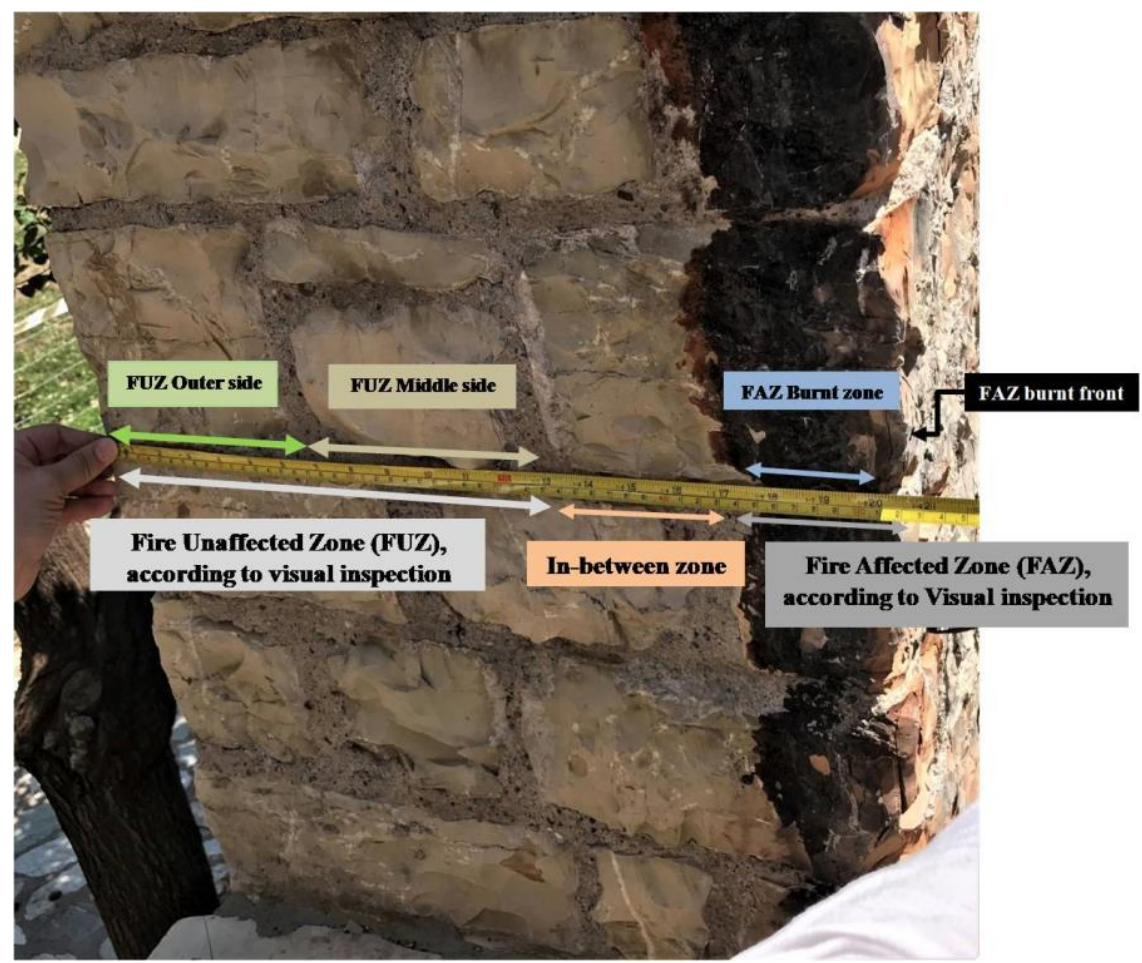

Figure 17. AREA 4: New masonry (Northern façade). The pillar is built from the beige-grey limestone. The examined areas by SHR are labeled.

Table 12. SHR values from the AREA 4 (see Figure 17).

\begin{tabular}{cccc}
\hline \multicolumn{4}{c}{ AREA 4 } \\
\hline Type of Fire-Affected Zone & Rm & Rmedian & COV\% \\
\hline & Fire Affected Zone (FAZ) & \\
\hline FAZ burnt front & $23.86 \pm 1.95$ & $23.50 \pm 2.50$ & 8.18 \\
FAZ burnt zone & $32.57 \pm 1.99$ & $33.50 \pm 2.50$ & 6.10 \\
\hline Zone between FAZ \& FUZ & $48.93 \pm 3.67$ & $48.50 \pm 3.10$ & 7.5 \\
\hline & Fire Unaffected Zone (FUZ) & \\
\hline FUZ middle side & $50.25 \pm 4.80$ & $49.50 \pm 5.50$ & 9.5 \\
FUZ outer side & $57.14 \pm 3.38$ & $56.00 \pm 4.00$ & 5.91 \\
\hline
\end{tabular}

\subsection{IRT Inspection}

IRT investigation took place on several parts of the new and the historical masonry, and some characteristic results are presented below.

The higher masonry part of the new masonry (above $1 \mathrm{~m}$ ) presents lower temperature readings compared to the lower masonry part, as well as an intermediate temperature distribution width of $3{ }^{\circ} \mathrm{C}$ (from $23^{\circ} \mathrm{C}$ to $27^{\circ} \mathrm{C}$ ), (Figure $18 \mathrm{a}-\mathrm{d}$ ). Regarding the lower masonry part, the lower stone zone presents higher temperatures (Figure 18c,d, zone under the dotted line) compared to the upper zone (Figure $18 \mathrm{c}, \mathrm{d}$, zone above the dotted line), as well as a tighter temperature distribution width of $2^{\circ} \mathrm{C}$ (from $26{ }^{\circ} \mathrm{C}$ to $28{ }^{\circ} \mathrm{C}$ ), whereas the upper zone displays a temperature distribution width of $4{ }^{\circ} \mathrm{C}$ (from $23.5^{\circ} \mathrm{C}$ to $27.5^{\circ} \mathrm{C}$ ). 

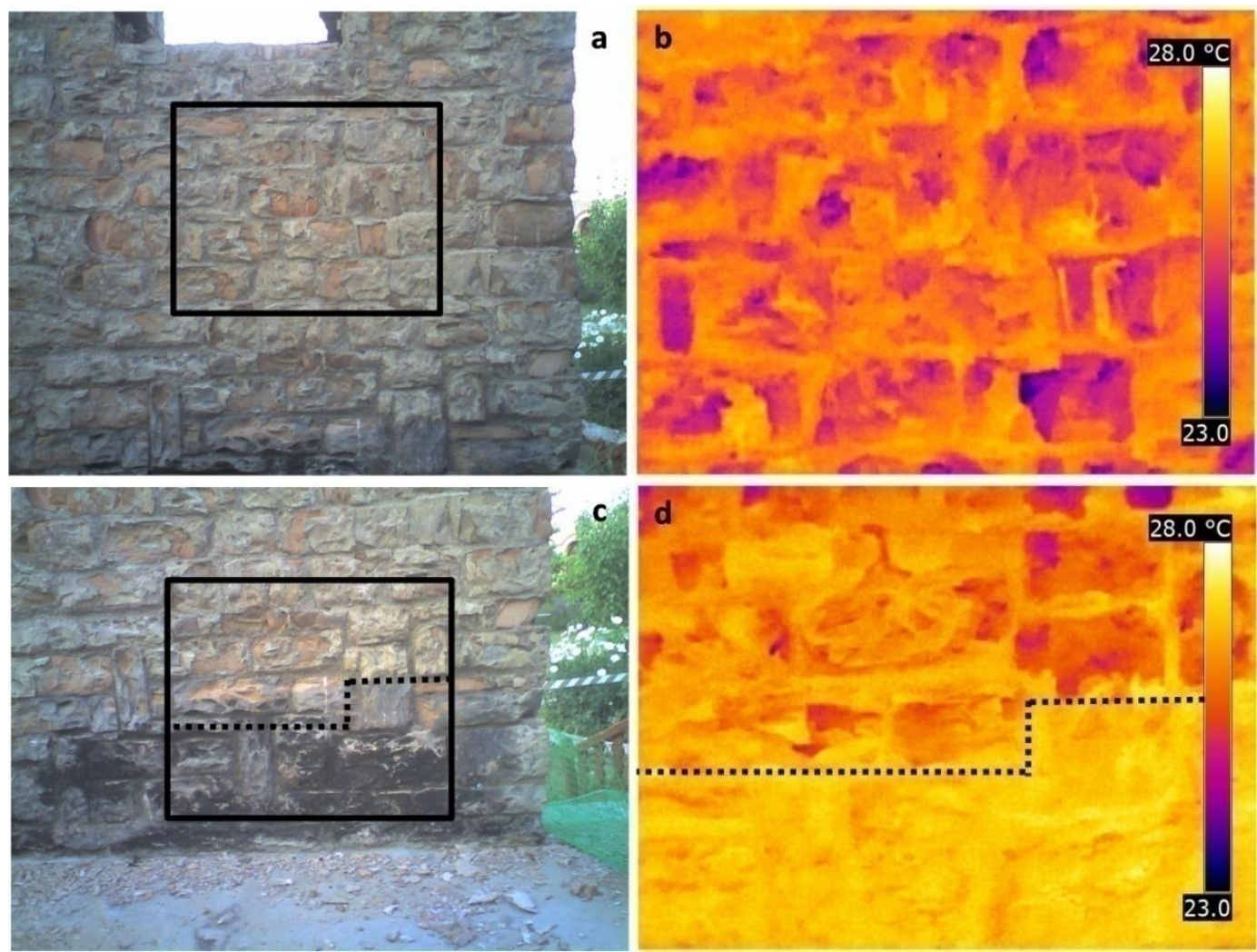

Figure 18. (a) Photo of the examined area 1 on the new masonry (higher masonry part). (b) Thermography of area 1. (c) Photo of the examined area 2 on the new masonry (lower masonry part-area 2 is below area 1). (d) Thermography of area 2.

It can be assumed by the 2 IRT images' co-evaluation that the new masonry presents different temperature zones height-wise. In particular, lower masonry parts display higher temperature readings compared to the upper masonry parts. This indicates a difference of the fire effect on the new masonry stone blocks, according to their height and position, even though a precise pattern is not demonstrated.

IRT investigation of the intermediate historical masonry shows temperature variations among the different stone types examined (Figure 19a,b), which are attributed to the different degree of the surface detachment/scaling due to the fire effect. The intermediate historical masonry presents a wide temperature distribution width of $4.5^{\circ} \mathrm{C}$ (from $22.5^{\circ} \mathrm{C}$ to $27^{\circ} \mathrm{C}$ ).
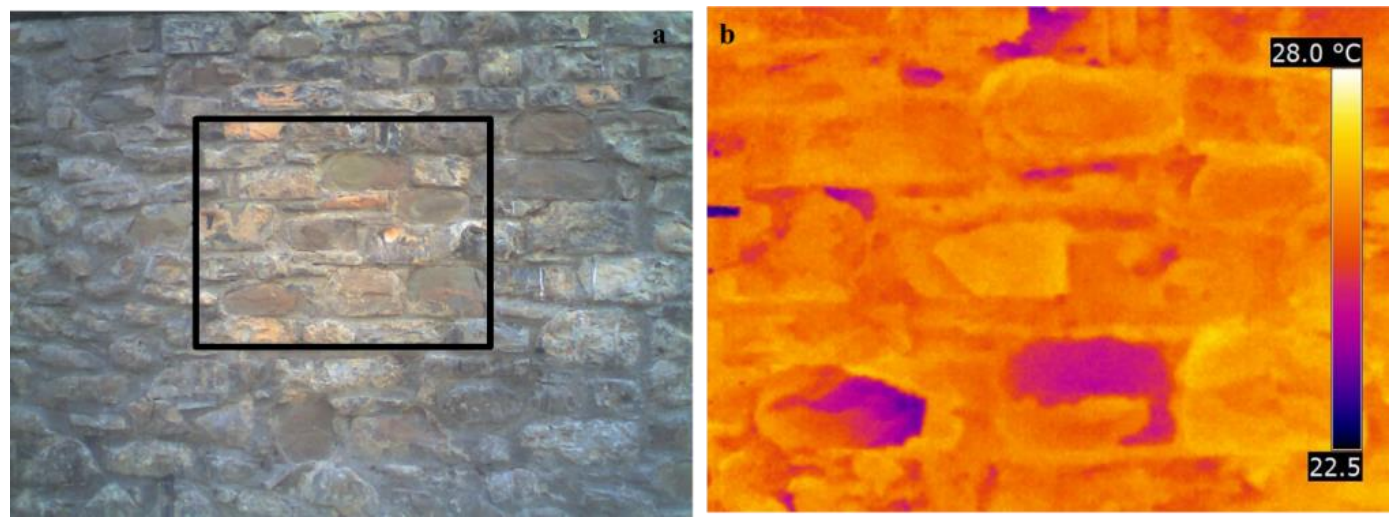

Figure 19. (a) Photo of the examined area 3 of the intermediate historical masonry. (b) Thermography of area 3. 
The application of IRT at higher historic masonry parts (above $2 \mathrm{~m}$ ) display lower temperature readings compared to the lower masonry parts (Figure 20). The wooden element in the middle of the IRT image presents temperatures up to $25.5^{\circ} \mathrm{C}$, while the masonry parts above and below it reach up to $26.8^{\circ} \mathrm{C}$. The temperature distribution width of the masonry, except the wooden element, is about $4.5^{\circ} \mathrm{C}$. Thus, it is demonstrated that the historic masonry holds a similar pattern with the new one, as far as it concerns temperature distribution. The upper masonry parts display lower temperatures when compared to the lower parts.
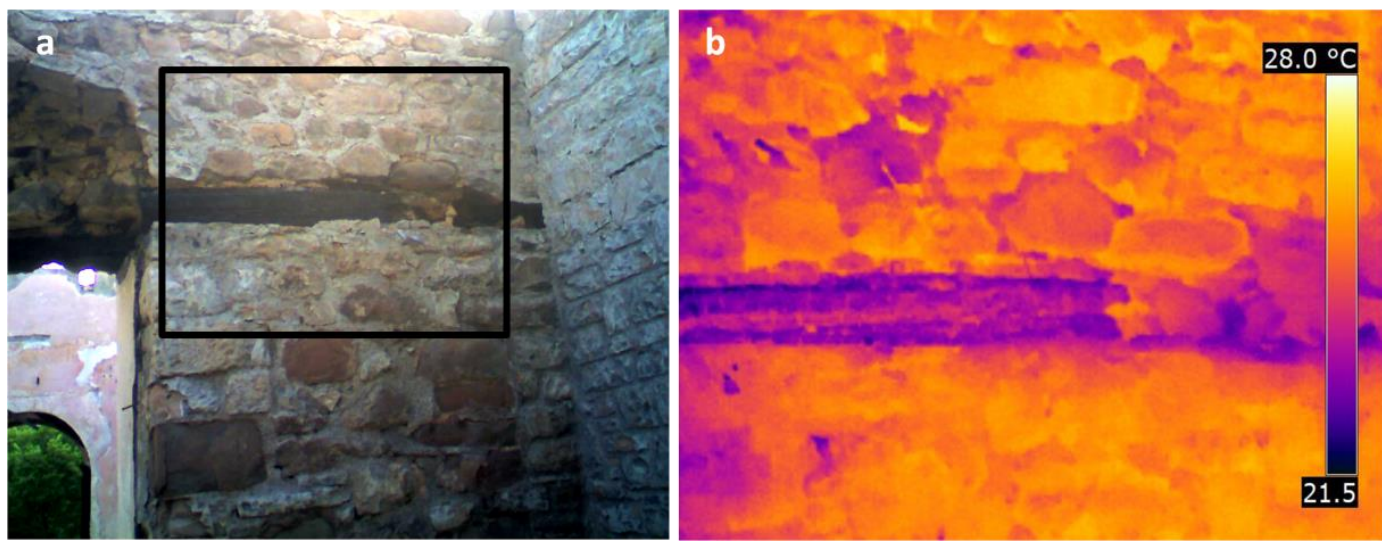

Figure 20. (a) Photo of the examined area 4 of the intermediate historical masonry. (b) Thermography of area 4

Furthermore, IRT investigation of the historical intermediate masonry surfaces that are blackened from the fire, records these areas with higher temperature readings (Figure 21); a result in accordance with the IRT examination of the respective areas of the new masonry. Temperature distribution width of the blackened surface is $2{ }^{\circ} \mathrm{C}$ (from $23.5^{\circ} \mathrm{C}$ to $25.5^{\circ} \mathrm{C}$ ), whereas the rest of the masonry area under investigation holds a temperature distribution width of $3{ }^{\circ} \mathrm{C}$ (from $22^{\circ} \mathrm{C}$ to $25^{\circ} \mathrm{C}$ ).
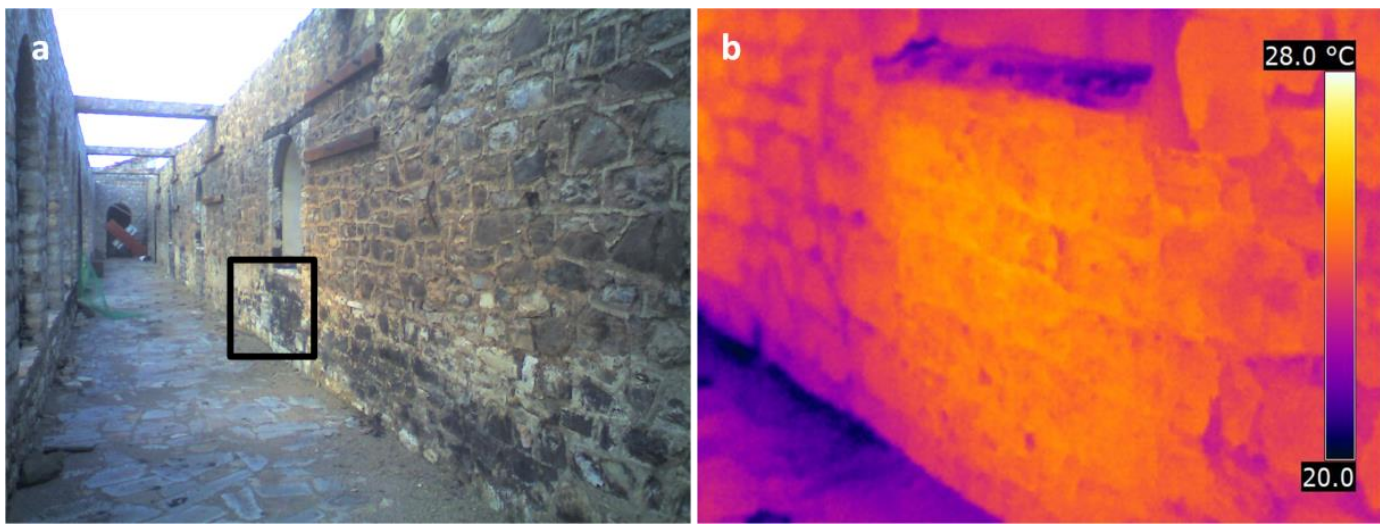

Figure 21. (a) Photo of the examined area 5 of the intermediate historical masonry. (b) Thermography of area 5.

\section{Conclusions}

During this preliminary study, the characterization of the different lithotypes and mortars used in the different architectural phases of Varnakova Monastery took place. The petrographic examination proved to be an indispensable tool for characterization and the fire impact assessment on the different lithotypes of the historic structure. The main building stones of the historic masonries are a beige-grey fosilliferrous biomicritic limestone, as well as a clastic calcite sandstone, consisting of crystalline 
and lithic fragments. Other stones are also sporadically detected, such as a black chert and a black fossiliferous limestone, which appears as laminae of the beige-grey fosilliferrous biomicritic limestone.

Regarding the main building stones, the petrographic examination of the fire-affected sandstone shows oxidation phenomena of iron-containing minerals due to the fire, which is macroscopically manifested by the reddening of the sample. While the fire-affected beige-grey limestone presents a pinkish hue macroscopically, due to the effect of the fire, the fire-effect is also evident through the widening and rupture of the joints filled with secondary calcite. The latter is more intense in the case of the limestone collected from the historical masonry.

Both XRD and thermal analysis measurements indicated distinct alterations of the sandstone due to the effect of fire. The microcline peak detected in the unaffected sample is not discerned in the fire-affected sample, while the calcite content also decreased. Physical properties of the sandstone are also altered. The effect of fire has increased porosity, decreased bulk density, and increased water absorption capacity. SHR values conducted in situ on a large number of sandstone building elements, both affected and unaffected, showed a decrease of surface hardness, as expected, in accordance with the degree of the fire exposure.

On the other hand, the limestone samples do not present distinct differences in their mineralogical, chemical, or physical properties due to the fire effect. However, the SHR evaluation reveals that, although relatively stable in the terms mentioned above, the effect of fire and the rupturing of the limestone's joints filled with secondary calcite are quantitatively evident in the decreased SHR values and, therefore, the decreased surface hardness. Further research is necessary in order to ascertain whether the mechanical strength values and especially compressive strength has also decreased, as expected. This highlights the need for further sampling to obtain samples of adequate geometry and dimensions in order to accomplish mechanical strength measurements. Such a sampling campaign requires further authorization, as the Monastery is a listed historical monument and is under a strict sampling legislation.

The mortars selected from the new masonry are classified as cement-based mortars, a fact which is anticipated in a recently constructed masonry. The thermal analysis and microstructure evaluation results demonstrate that these mortars are highly carbonated due to the fire effect. The mortars selected from the intermediate historical masonry belong to two categories: clay mortars and cement-based mortars. All structural mortars belong to the clay mortars category, while the final joint mortars belong to the cement-based category, which demonstrate that recent repointing had taken place using a cement-based mortar, prior to the fire event. Digital microscopy observations regarding the texture of the mortars proved to be a useful tool for an initial classification.

IRT inspection of the masonries as a whole, demonstrates that the historic masonry presents relatively high temperature variations, due to the presence of diverse lithotypes, as well as the different degree of the fire effect. Similar fluctuation of temperatures is observed for the new masonry as well, despite the fact that it is entirely built from one lithotype (namely the grey-beige limestone) and can be attributed to the fire event.

Both historical and new masonries present different temperature zones with their upper parts being cooler than the lower ones. This is an indication of the different effect of the fire per height. However, even though the fire effect seems to depend on position, height, and lithotype, no clear pattern is displayed.

Blackened surfaces, in both the historical and new masonries, present higher temperatures, which indicate differences in the thermo-hygric behavior of the masonry in these areas, due to soot accumulation from the fire, as well as a possible stronger fire damaging effect.

It is evident from the IRT results that the historical masonry presents wider temperature distribution width in comparison to the new masonry. However, the recorded temperature readings of the historical masonry are lower in comparison to the ones of the new masonry. These differences are attributed to the differentiated development of the fire event, as well as to the fire's different effect on the historical masonry, due to the variety of building materials comprising it. 
The results of the present study provide information regarding the characterization of the building materials of the Varnakova cell's quarter and diagnosis of their decay due to the fire event. The techniques implemented have proven valuable for evaluating the present state of the masonries. These results can serve as a basis for further investigation, which are necessary in order to plan appropriate restoration and conservation strategies for the rehabilitation of the cells' quarter in terms of sustainability.

Author Contributions: E.T.D. offered the methodology about materials characterization and nondestructive testing, and supervised the in situ investigation and sampling, all related measurements, and the overall writing of the paper. M.A. participated in the in situ investigation and sampling, as well as implemented and supervised the investigation related to thermal analysis measurements. Elaborated total water immersion tests and conducted writing and editing of the paper. I.N. conducted the writing of the original draft, elaborated the SHR measurements, and performed the DM measurements. M.T. assisted in the in situ investigation and sampling and implemented the investigation of the building materials. V.K. implemented the investigation of the building materials and performed the total water immersion tests. C.P. and G.E. implemented and supervised the microscopy and mineralogical measurements. A.M. was responsible for the scientific administration and scientific supervision of the research team, the scientific conceptualization and visualization of the project and research conducted.

Funding: This research received no external funding.

Acknowledgments: The authors would like to thank the Abbess and the Sisterhood of the Varnakova Monastery, as well as Ch. Alexopoulou, Civil Engineer, and S. Fidani, for inviting Professor Moropoulou and the NTUA team to undertake the diagnostic study of the Church and the Cells. In addition, the authors would like to acknowledge the Central Greece Regional unit, the Governor of Central Greece, K. Bakoyannis, the Regional Councilor, P. Aravantinou, as well as the General Directorate of Antiquities and Cultural Heritage of the Ministry of Culture and Sports of the Hellenic Republic and the Ephorate of Antiquities of Phocis, A. Psalti, for their fruitful cooperation. Lastly, the authors would like to thank NTUA Associate Professor Ch. Mouzakis for the interdisciplinary cooperation, which we anticipate to continue through a Program Agreement with the Ministry of Culture and Sports and the Central Greece Region. This research was orally presented in its initial form at the 1st International Conference TMM_CH: Transdisciplinary Multispectral Modeling and Cooperation for the Preservation of Cultural Heritage, held on 10-13 October 2018 at the Eugenides Foundation Athens, Greece under the title "The effect of fire on building materials: the case-study of the Varnakova monastery cells in Central Greece" by I. Ntoutsi, E. T. Delegou, M. Thoma, M. Apostolopoulou, Ch. Papatrechas, G. Economou, and A. Moropoulou. It has since then been modified and elaborated with further results and interpretations. Lastly, we would like to thank the anonymous reviewers for their valuable suggestions and comments during the manuscript's revision process.

Conflicts of Interest: The authors declare no conflict of interest.

\section{References}

1. Brotóns, V.; Tomás, R.; Ivorra, S.; Alarcón, J.C. Temperature influence on the physical and mechanical properties of a porous rock: San Julian's calcarenite. Eng. Geol. 2013, 167, 117-127. [CrossRef]

2. Kompaníková, Z.; Gomez-Heras, M.; Michňová, J.; Durmeková, T.; Vlčko, J. Sandstone alterations triggered by fire-related temperatures. Environ. Earth Sci. 2014, 72, 2569-2581. [CrossRef]

3. Ozguven, A.; Ozcelik, Y. Effects of high temperature on physico-mechanical properties of Turkish natural building stones. Eng. Geol. 2014, 183, 127-136. [CrossRef]

4. Vázquez, P.; Shushakova, V.; Gómez-Heras, M. Influence of mineralogy on granite decay induced by temperature increase: Experimental observations and stress simulation. Eng. Geol. 2015, 189, 58-67. [CrossRef]

5. Sanjurjo-Sánchez, J.; Gomez-Heras, M.; Fort, R.; Alvarez de Buergo, M.; Izquierdo Benito, R.; Angel Brud, M. Dating fires and estimating the temperature attained on stone surfaces. The case of Ciudad de Vascos (Spain). Microchem. J. 2016, 127, 247-255. [CrossRef]

6. Calia, A.; Colangiuli, D.; Lettieri, M.; Quarta, G.; Masieri, M. Microscopic techniques and a multi-analytical approach to study the fire damage of the painted stuccoes from the Petruzzelli Theatre (Bari, Southern Italy). Microchem. J. 2016, 126, 42-53. [CrossRef]

7. Freire-Lista, D.M.; Fort, R.; Varas-Muriel, M.J. Thermal stress-induced microcracking in building granite. Eng. Geol. 2016, 206, 83-93. [CrossRef] 
8. Peng, J.; Rong, G.; Cai, M.; Yao, M.; Zhou, C. Comparison of mechanical properties of undamaged and thermal-damaged coarse marbles under triaxial compression. Int. J. Rock Mech. Min. Sci. 2016, 83, 135-139. [CrossRef]

9. Vazquez, P.; Acuñab, M.; Benavente, D.; Gibeaux, S.; Navarro, I.; Gomez-Heras, M. Evolution of surface properties of ornamental granitoids exposed to high temperatures. Constr. Build. Mater. 2016, 104, $263-275$. [CrossRef]

10. Ingham, J.P. Application of petrographic examination techniques to the assessment of fire-damaged concrete and masonry structures. Mater. Character. 2009, 60, 700-709. [CrossRef]

11. Martinho, E.; Mendes, M.; Dionísio, A. 3D imaging of P-waves velocity as a tool for evaluation of heat induced limestone decay. Constr. Build. Mater. 2017, 135, 119-128. [CrossRef]

12. McCabe, S.; Smith, B.J.; Warke, P.A. Exploitation of inherited weakness in fire-damaged building sandstone: The 'fatiguing' of 'shocked' stone. Eng. Geol. 2010, 115, 217-225. [CrossRef]

13. Murru, A.; Freire-Lista, D.M.; Fort, R.; Varas-Muriel, M.J.; Meloni, P. Evaluation of post-thermal shock effects in Carrara marble and Santa Caterina di Pittinuri limestone. Constr. Build. Mater. 2018, 186, 1200-1211. [CrossRef]

14. Haaland, M.M.; Friesem, D.E.; Miller, C.E.; Henshilwood, C.S. Heat-induced alteration of glauconitic minerals in the Middle Stone Age levels of Blombos Cave, South Africa: Implications for evaluating site structure and burning events. J. Arch. Sci. 2017, 86, 81-100. [CrossRef]

15. Felicetti, R. The drilling resistance test for the assessment of fire damaged concrete. Cem. Concr. Compos. 2006, 28, 321-329. [CrossRef]

16. Khoury, G.A. Effect of fire on concrete and concrete structures. Prog. Struct. Eng. Mater. 2000, 2, 429-447. [CrossRef]

17. Kardamitsi-Adami, M. The Catholikon of the Monastery Varnakova and the Architect Andreas Gasparis Kalandros. Archaiologia 2011, 6, 78-84.

18. Bouras, Ch.; Boura, L. Church Architecture in Greece around the 12th Century; Commercial Bank of Greece: Athens, Greece, 2002.

19. Zacharopoulos, S. Topographical Study of the Holy Monastery of Panagia Varnakova, Field Report; Greece, 2002.

20. Moropoulos, N. World Monuments Watch: Holy Monastery of Panagia Varnakova. 2019. submitted.

21. Orlandos, A. The Monastery of Virgin Mary of Varnakova; Doric Association of Athens: Athens, Greece, 1922.

22. Available online: https://www.newsit.gr/topikes-eidhseis/naypaktos-megali-fotia-tora-stin-iera-monivarnakovas/1085140/ (accessed on 10 September 2018).

23. Borelli, E. ARC Laboratory Handbook: Conservation of Architectural Heritage, Historic Structures and Materials. 2. Porosity; International Centre for the Study of the Preservation and the Restoration of Cultural Property: Rome, Italy, 1999.

24. Demirdag, S.; Yavuz, H.; Altindag, R. The effect of sample size on Schmidt rebound hardness value of rocks. Int. J. Rock Mech. Min. Sci. 2009, 46, 725-730. [CrossRef]

25. Fort, R.; Alvarez de Buergo, M.; Perez-Monserrat, E.M. Non-destructive testing for the assessment of granite decay in heritage structures compared to quarry stone. Int. J. Rock Mech. Min. Sci. 2013, 61, 296-305. [CrossRef]

26. Matthews, J.A.; Owen, G.; Winkler, S.; Vater, A.E.; Wilson, P.; Mourne, R.W.; Hill, J.L. A rock-surface microweathering index from Schmidt hammer R-values and its preliminary application to some common rock types in southern Norway. Catena 2016, 143, 35-44. [CrossRef]

27. Proceq. Operating Instructions Beton Prüfhammer N/NR-L/LR; Proceq SA: Schweizenbach, Zurich, Switzerland, 2006.

28. Vasanelli, E.; Sileo, M.; Calia, A.; Aiello, M.A. Non-destructive techniques to assess mechanical and physical properties of soft calcarenitic stones. Procedia Chem. 2013, 8, 35-44. [CrossRef]

29. Vasanelli, E.; Calia, A.; Colangiuli, D.; Micelli, F.; Aiello, M.A. Assessing the reliability of non-destructive and moderately invasive techniques for the evaluation of uniaxial compressive strength of stone masonry units. Constr. Build. Mater. 2016, 124, 575-581. [CrossRef]

30. Alexakis, E.; Delegou, E.T.; Lampropoulos, K.C.; Apostolopoulou, M.; Ntoutsi, I.; Moropoulou, A. NDT as a monitoring tool of the works progress and the assessment of materials and rehabilitation interventions at the Holy Aedicule of the Holy Sepulchre. Constr. Build. Mater. 2018, 189, 512-526. [CrossRef] 
31. Borg, R.P.; Hajpál, M.; Torok, Á. The fire performance of limestone. In Applications of Structural Fire Engineering 2013; Czech Technical University: Prague, Czech Republic, 2013.

32. Sirdesai, N.N.; Mahanta, B.; Ranjith, P.G.; Singh, T.N. Effects of thermal treatment on physico-morphological properties of Indian fine-grained sandstone. Bull. Eng. Geol. Environ. 2019, 78, 883-897. [CrossRef]

33. Moropoulou, A.; Bakolas, A.; Anagnostopoulou, S. Composite materials in ancient structures. Cem. Concr. Compos. 2005, 27, 295-300. [CrossRef]

34. Moropoulou, A.; Polikreti, K.; Bakolas, A.; Michailidis, P. Correlation of physicochemical and mechanical properties of historical mortars and classification by multivariate statistics. Cem. Concr. Res. 2003, 33, 891-898. [CrossRef]

(C) 2019 by the authors. Licensee MDPI, Basel, Switzerland. This article is an open access article distributed under the terms and conditions of the Creative Commons Attribution (CC BY) license (http://creativecommons.org/licenses/by/4.0/). 